\title{
Bank regulation, risk and return: Evidence from the credit and sovereign
}

\section{debt crises}

\author{
Hafiz Hoque $^{\mathrm{a}, *}$, Dimitris Andriosopoulos ${ }^{\mathrm{b}}, \operatorname{Kostas}^{\text {Andriosopoulos }}{ }^{\mathrm{c}}$, Raphael Douady \\ ${ }^{a}$ University of York, Freboys lane,YO10 5GD,York, United Kingdom \\ ${ }^{\mathrm{b}}$ Strathclyde University, 100 Cathedral Street, G4 OLN, Glasgow, United Kingdom \\ ${ }^{\mathrm{c}}$ ESCP Europe Business School,527 Finchley Road, NW3 7BG London, United Kingdom \\ ${ }^{\mathrm{d}}$ CNRS, University Paris 1 Pantheon-Sorbonne, and Riskdata, France
}

\begin{abstract}
In this paper, we analyze whether regulation reduced risk during the credit crisis and the sovereign debt crisis for a cross section of global banks. In this regard, we examine distance to default (Laeven and Levine, 2008), systemic risk (Acharya et al., 2010), idiosyncratic risk, and systematic risk. We employ World Bank survey data on regulations to test our conjectures. We find that regulatory restrictions, official supervisory power, capital stringency, along with private monitoring can explain bank risk in both crises. Additionally, we find that deposit insurance schemes enhance moral hazard, as this encouraged banks to take on more risk and perform poorly during the sovereign debt crisis. Finally, official supervision and private monitoring explains the returns during both crisis periods.
\end{abstract}

Keywords: Distance to default, systemic risk, idiosyncratic risk, beta, buy-and-hold returns, regulations.

JEL classifications: E44, G2, G20, G28.

*Corresponding author: Tel.: +44 (0)1904325047.

E-mail addresses: hafiz.hoque@york.ac.uk (H. Hoque), d.andriosopoulos@ strath.ac.uk (D. Andriosopoulos), kandriosopoulos@escpeurope.eu (K. Andriosopoulos), raphael.douady@riskdata.com (R. Douady). 


\section{Introduction}

Journalists, policymakers, and academics have argued that lenient regulations, reliance on short-term funding, excessive risk taking, and corporate governance failure are responsible for the recent crisis. This paper examines the impact of regulations on the risk and returns of global banks during the credit and sovereign debt crises. We examine an extensive sample of large international banks that are the targets of current regulatory efforts while many of them are considered to be too big to fail by central banks. These banks are characterized by their large capitalization, global activity, cross-border exposure, and/or representative size in the local industry. In this regard, we examine the determinants of distance to default (Laeven and Levine, 2008), systemic risk (marginal expected shortfall [MES] proposed by Acharya et al., 2010), idiosyncratic risk, and systematic risk.

There is scant literature examining the impact of bank regulations on bank fragility and risk. Demirgüç-Kunt and Detragiache (2011) use the adherence to the core principles from the Basel Committee on Bank Supervision and show that bank supervision and regulation have very little effect on bank risk. Barth et al. (2004) use the World Bank survey data II and show that countries with higher regulatory restrictions have a higher probability of experiencing a banking crisis. Barth et al. (2013) show that banking restrictions are negatively related to bank efficiency. To the best of our knowledge, no prior studies examine the impact of World Bank regulations on bank risk and return during the recent credit and sovereign debt crises. We fill this gap in the literature and take this opportunity to examine the effectiveness of World Bank regulations in terms of bank risk taking and returns.

We use the 2008 World Bank survey on bank regulation data to examine whether lenient regulations were responsible for excessive risk taking by the banks, which led them to perform badly during the crisis (Stiglitz, 2010). The banking regulations survey contains 312 questions on different dimensions, and most of the questions require yes/no type of answers. 
We form scores for measuring different dimensions and following Beltratti and Stultz (2012) and Pasiouras et al. (2006), we classify the survey questions used into five categories: (1) capital regulations; (2) restrictions on bank activities; (3) official supervisory power; (4) private monitoring; and (5) deposit insurance. We test whether capital regulations, restrictions on bank activities, official supervisory power, private monitoring, and deposit insurance are related to risk and whether they affected the banks' stock performance during the credit and sovereign debt crises. We perform our tests on a number of different risk measurements.

Our first measure of risk is the distance to default $(\log z)$, as in Laeven and Levine (2009). Log z measures the distance from bankruptcy (Roy, 1952). Since a large number of banks went bankrupt following the credit and sovereign debt crises, it is imperative and timely to examine whether regulations have any impact on global banks' distance to default risk during these periods of turmoil. Our second measure of risk is the systemic measure of risk, MES. The use of individual banks' contribution to systemic risk is relatively new and allows us to test the effects of regulations during the credit and sovereign debt crisis. Most of the earlier empirical work has examined the relationship between regulation and systemic stability by using the incidence of banking crisis at the country level as a measure of systemic risk (e.g., Demirgüç-Kunt and Detragiache, 2002). We examine the impact of regulation on individual banks' contribution to the overall systemic risk. Our third measure of risk is the idiosyncratic risk of banks. Fahlenbrach et al. (2012) argue that banks have learned from previous financial crises, leading banks to change their behavior and protect themselves from a future financial crisis. In light of the regulatory changes that occurred after the credit crisis, we assess whether banks changed their business models by taking risk more sensibly, as captured by idiosyncratic risk. Our final measure of risk is banks' systematic risk which is 
estimated based on the market model. We also examine whether regulations impacted banks' systematic risk during the credit and sovereign debt crisis.

Bank supervisors form their assessments on bank risk based on their proprietary information. However, this information is accessed over infrequent intervals. Moreover, the daily change of market variables reflects bank risk in a timelier manner, but does not fully reflect all the information that is available to supervisors (Berger et al., 2000). Therefore, the information on bank risk, which is inherent in equity market variables, can complement supervisory assessment markets (Gunther et al., 2001; Hall et al., 2001; Elmer and Fissel, 2001; Curry et al., 2001).To assess whether the market variables explain risk, we include buy-and-hold abnormal return (BHAR) calculated before the credit and sovereign debt crises. ${ }^{1}$ Since return is the reward for taking risk, we evaluate the impact of regulations on banks' stock performance.

Our results show that restrictions, private monitoring, and deposit insurance explain the distance to default during the credit crisis, while official power and private monitoring had a consistent impact on banks during the sovereign debt crisis. However, we do not find any evidence of deposit insurance having an impact. Following the credit crisis, official supervisory power has a significant impact on banks' distance to default. This suggests that countries with higher official power could take the necessary corrective actions and strengthen their banking system. Additionally, we find that deposit insurance explains the distance to default during the credit crisis, but not in the sovereign debt crisis. We argue that as sovereign states were affected during the sovereign debt crisis, they were unable to support banks at the time. Hence, banks in countries with deposit insurance schemes have a higher probability to default.

\footnotetext{
${ }^{1}$ We thank an anonymous referee for this suggestion.
} 
Regarding our second risk measurement (MES) we find that activity restrictions and deposit insurance explain MES during the credit and the sovereign debt crisis. Capital restrictions also explain MES but only during the sovereign debt crisis. This is due to the fact that not only Tier I capital requirements have increased, but the quality requirements of capital have also increased. After the credit crisis, there have been significant changes in terms of capital adequacy and stress testing. We find that banks in countries with stricter capital requirements have lower systemic risk contributions.

The results on the third risk measurement, idiosyncratic risk, show that with greater official power and in the presence of deposit insurance schemes, banks take more risk resulting in higher idiosyncratic risk during the credit crisis. However, official power is no longer significant during the sovereign debt crisis. We argue that this could be due to the fact that banks became significantly fragile and therefore, regulators could not exert benefits anymore. Finally, we find a positive relationship between deposit insurance and idiosyncratic risk during both crisis periods, reinforcing the view that deposit insurance increases moral hazard.

We also examine whether regulations impacted banks' systematic risk during the credit and sovereign debt crisis. We find that higher official power results in banks having higher systematic risk. This suggests that rent extraction by the regulators is also reflected by market risk. Additionally, banks in countries with higher capital restrictions are more protected in case of financial turmoil, and private monitoring prevents banks from taking riskier decisions, as reflected by a lower systematic risk. These findings hold for both the credit and sovereign debt crises. BHAR is significant in most of the risk regressions, suggesting that market variables reflect bank risk in a timely manner. Hence, regulators should complement their decisions with the information inherent in market variables. Our results have other policy implications. 
The rest of the paper is organized as follows. In section 2, we develop the hypotheses. In section 3, we perform a descriptive analysis of the credit and the sovereign debt crises. Section 4 describes the variables used and employed methodology. Section 5 discusses the data sources and descriptive statistics. Section 6 presents the results on the impact of regulation on risk and returns during the credit and sovereign debt crises. In section 7, we conduct robustness checks. The conclusions are in section 8 .

\section{Hypothesis development for testing the impact of regulations on bank risk and} returns

We take advantage of the 2008 World Bank survey on bank regulation data to examine whether lenient regulations were responsible for excessive risk taking by the banks, which led them to perform badly during the crisis. Following Beltratti and Stultz (2012) and Pasiouras et al. (2006), we classify the survey questions used into five categories: (1) capital regulations; (2) restrictions on bank activities; (3) official supervisory power; (4) private monitoring; (5) deposit insurance. Since, excessive risk taking is primarily blamed for the crisis (Beltratti and Stultz, 2012), in this section, we show that these five categories of regulations can relate to the risk-taking behavior of the banks. Therefore, we focus on these five categories of regulations to develop and test our hypotheses. Finally, due to the conflicting theoretical predictions, it is an empirical question whether bank regulations have a positive or negative impact on bank risk and returns.

\subsection{Bank capital and capital regulation}

Core (Tier I) capital is at the focal point of banking regulation, as it helps banks when they face liquidity problems. Likewise, an index of regulatory capital oversight looks at the quality of regulatory capital held by the banks. In this section, we pay attention at the quantity and quality of regulatory capital. Previous research finds that stringent capital requirements 
reduce banking risk (Fernandez and González, 2005). We test the importance of capital adequacy and respective capital-requirement regulations and how they can impact banks and their tendency on risk taking and performance during the recent crises.

Bank regulations stress the benefits of capital adequacy requirements (Dewatripont and Tirole, 1994), as adequate capital enables banks to absorb unexpected losses and thus remain solvent. Likewise, banks with limited liability are less prone to assume more risk with larger amounts of capital at risk. Berger et al. (1995) and Keeley and Furlong (1990) argue that capital adequacy requirements along with deposit insurance can have a significant effect on aligning the incentives of bank owners with those of depositors and other creditors.

However, theory offers contradictory predictions as to whether the imposition of capital requirements will have positive effects (see Santos, 2001; Gorton and Winton, 2003). A number of studies argue that capital requirements may increase risk-taking behavior (Koehn and Santomero, 1980; Kim and Santomero, 1988; Besanko and Kanatas, 1996; and Blum, 1999). Similarly, Thakor (1996) models the effect of risk-based capital requirements on bank asset allocation decisions when screening borrowers is costly. Assuming that equity capital is more expensive to raise than deposits, then an increase in risk-based capital requirements reduces the banks' tendency to screen investment opportunities and increase their lending. Gorton and Winton (2000) show that in a general equilibrium framework, the increase of capital requirements has an inverse impact on banks' supply of deposits, hence reducing the traditional liquidity-provision role of banks.

We use the recent credit and sovereign debt crises and address the theoretical contradictions on capital adequacy requirements along with the shift on new risk-based capital requirements in Basel II and III accords. We do so by examining the impact of capital requirements, regarding Tier I capital, on bank risk and stock performance across countries. Alternatively, we use Capital, an index of regulatory oversight of bank capital. This capital 
index also includes indicators for capital sources, other than cash and government securities, that are included in regulatory capital and whether authorities verify the source of capital. During a crisis we expect the banks to benefit from higher capital requirements. Hence, our first hypothesis is:

Hla: Higher capital requirements reduce bank risk during financial turmoil.

H1b: Higher capital requirements increase banks'stock returns during financial turmoil.

\subsection{Restrictions on Bank Activities}

If banks are allowed to do a broad range of activities they might engage in risky ventures that can be suboptimal for investors (Boyd et al., 1993). Restricting bank activities means imposing restrictions on activities and securities banks may hold. Since bank assets are opaque, during a financial turmoil the value of risky securities can decline significantly. Limiting risky undertakings may decrease the financial losses given the opacity of bank assets. However, the results of Barth et al. (2004) indicate the opposite: restricting bank activities is negatively related to bank stability and increases the probability of a banking crisis. Therefore, we examine the relationship between activity restrictions and risk taking and returns during the recent financial and sovereign debt crises as it can assist in assessing the effectiveness of restrictions.

According to Barth et al. (2004), the reasoning for restricting bank activities and banking commerce rests on five hypothetical reasons. First, there can be significant conflicts of interest if banks are involved in diverse activities such as securities and insurance underwriting and real estate investment. For instance, banks may try to "push" securities of troubled firms to uninformed investors (John et al., 1994; Saunders, 1985). Second, due to moral hazard, if banks are allowed to diversify their operations and range of activities, they will be more likely to engage in riskier investments, thus increasing their risk (Boyd et al., 
1998). Third, the size and complexity of certain banks makes them difficult to monitor. Fourth, such banks may become so politically and economically powerful that they become "too big to discipline" (Laeven and Levine, 2007). Finally, large financial conglomerates can stifle competition and reduce banking efficiency (Barth et al., 2013). Based on these arguments, government supervision and regulation can improve banking by restricting bank activities. Moreover, these arguments imply a negative relationship between activity restrictiveness and bank risk and a positive relationship between return and activity restrictions.

However, there are alternate theoretical reasons for permitting banks to engage in a broader range of activities. For instance, less supervisory restriction will allow banks to better utilize economies of scale and scope (Claessens and Klingebiel, 2000). Moreover, fewer regulatory restrictions might increase the banks' franchise value, thus increasing their incentive to adopt prudent behavior. Finally, if banks are allowed to engage in a wider array of activities, this will increase their income diversification, resulting in better stability. The empirical evidence largely shows that restricting bank activities has adverse outcomes. In a cross-country investigation, Barth et al. (2001) find that more regulatory restrictions on bank actions are related to a higher probability of suffering a major banking crisis and lower banking sector efficiency. Barth et al. (2004) find that restricting bank activities is not related to less concentration, more competition, or greater securities market development. Barth et al. (2013) find that tighter restrictions are negatively associated with bank efficiency. What is more, bank restrictions can be designed in such a manner that they give regulators discretion and thus enhance their bargaining power for rent seeking (Djankov et al., 2002). In summary, there are contradicting views on the effects of activity restrictions, and therefore, we assess empirically the effect of activity restrictions during the credit and sovereign debt crises on bank risk and return. Our testable hypotheses are as follows: 
H2a: Greater restrictions to banking activities reduce bank risk during financial turmoil.

H2b: Greater restrictions to banking activities increase banks' stock returns during financial turmoil.

\subsection{Official Supervisory Power}

Supervisory power can affect risk taking, and during turbulent times, supervisors should be able to perform corrective actions. Stringent supervisory control can potentially prevent managers from engaging in excessive risk-taking behavior. There are evidence (e.g., Fernandez and González, 2005) and contra evidence (e.g., Barth et al., 2004) on that issue. Since we observe two crises with a short time lapse between them, and official supervisory power is a core part of World Bank regulations, we examine whether risk taking depends on monitoring and supervisory power.

It is costly and difficult to monitor banks and yet too little monitoring would lead to suboptimal performance. Therefore, greater official supervision and monitoring can mitigate this suboptimal performance (Beck et al., 2006). Moreover, banks can be susceptible to bank runs and respective contagion due to information asymmetries. Supervision can reduce information asymmetries and help protect banks from potential bank runs to a certain extent. In addition, greater official supervision can help reduce the inherent moral hazard of deposit insurance schemes - as deposit insurance can lead banks to take excessive risks - and at the same time reduce the depositors' incentives for privately monitoring the banks. In this regard, supervisory power is expected to be positively associated with bank returns and negatively associated with risk.

To the contrary, powerful supervisors may use their powers to benefit favored voters, attract campaign donations, and extract bribes (Shleifer and Vishny, 1998; Djankov et al., 2002; Quintyn and Taylor, 2002). Therefore, more powerful supervision can lead to 
corruption and hurting bank performance and stability. Kane (1990) and Boot and Thakor (1993) focus on a different perspective, which is the agency costs between bank supervisors and taxpayers. Rather than focusing on political influence, Boot and Thakor (1993) model the behavior of a self-interested bank supervisor when there is uncertainty about the supervisor's ability to monitor banks. Under these settings, they show that supervisors might lead to socially suboptimal arrangements. Thus, greater supervision can hinder bank operations when conditional on bank supervisors' incentives and the ability of taxpayers to monitor supervision. As Beck et al. (2006) argue, if bank supervisory agencies have the authority to discipline noncompliant banks, the supervisors might use this power to induce or force banks to allocate credit so as to generate private or political benefits. As a consequence, supervisor power might be negatively associated with bank returns and positively associated with risk. During a crisis we expect banks to benefit from higher supervisory power. Our hypotheses on supervisory power are stated as follows:

H3a: Greater supervisory power reduces bank risk during financial turmoil.

H3b: Greater supervisory power increases banks'stock returns during financial turmoil.

\subsection{Private monitoring}

Apart from regulatory supervision and monitoring, shareholders can also monitor banks' operations and performance and influence their policy through investors' monitoring ability. Related to this market-based view of regulations where market reward good banks and penalize bad ones, Fernandez and González (2005) find that regulations that promote and assist private monitoring of banks increase banks' financial soundness by reducing moral hazard created by information asymmetries. Therefore, this section provides a discussion on how private monitoring can substitute or complement regulators' supervision and affect bank's attitude towards risk taking and performance during the recent financial crisis. 
Private monitoring can be motivated and enhanced by official bank supervisors. For instance, Barth et al. (2006) find that some regulatory agencies require banks to obtain certified audits and/or ratings from international rating agencies and to produce accurate, comprehensive, and consolidated information on the full range of their activities and risk management procedures. A set of countries also hold bank directors legally liable if information is erroneous or misleading. Also, some countries enact deliberately a "no deposit insurance" policy to stimulate private monitoring. Nevertheless, there are opposing views regarding the role and impact of bank monitoring by the private sector. One view argues for greater reliance on private monitoring and against official supervision. Shleifer and Vishny (1998) argue, regarding government regulations, that banks will put pressure on politicians who, in turn, can inappropriately exert influence on the supervisory oversight. Moreover, regulators do not invest their own wealth in banks, resulting in a divergence of their incentives, in terms of monitoring and disciplining banks, with those of private creditors. In contrast, another view argues for less reliance on private monitoring. Countries with under-developed capital markets and weak accounting standards and legal systems might not be able to rely effectively on private monitoring. Moreover, the fact that banks are complex and opaque institutions makes it difficult for private monitoring to keep up even in the most developed economies. Therefore, a greater reliance on private monitoring of banks may lead eventually to the exploitation of depositors and poor bank performance (Barth et al., 2004). We explore the effect of these supervisory schemes on bank risk taking and performance during the credit and sovereign debt crises. Our hypotheses are as follows:

H4a: Greater private monitoring reduces bank risk during financial turmoil.

H4b: Greater private monitoring increases banks' stock returns during financial turmoil. 


\subsection{Deposit insurance}

During the credit crisis deposit insurance schemes came in the limelight and are considered as one of the tools in the regulators' disposal for preventing the credit crisis from spreading further in the financial services system. On the other hand, the moral hazard in presence of deposit insurance induces banks to engage in excessive risk taking (Barth et al., 2004) and Demirgüç-Kunt and Detragiache, 2002) Therefore, in this section, we discuss how the presence of deposit insurance can affect risk taking and how it affects performance. The effectiveness and role of deposit insurance can be evaluated once a crisis happens. Hence, we examine the role of deposit insurance on risk taking by global banks during the credit and sovereign debt crises.

In order to protect banks that experience liquidity problems but remain solvent, countries adopt deposit insurance schemes in order to prevent bank runs. Since deposit insurance can safeguard payment and credit systems overall, it enjoys a great number of supporters. Starting with Merton (1977), a number of theoretical papers have studied the relationship between deposit insurance and banking sector stability. This positive stabilization effect of deposit insurance obviously has greater importance during economic downturns when contagion is more likely to spread and bank runs are more likely to occur. Consistent with this view, Gropp and Vesala (2004) show that the adoption of deposit insurance is related to lower bank risk in the European Union. Similarly, Chernykh and Cole (2011) show that the adoption of deposit insurance in Russia created safer banks. For US credit unions, Karels and McClatchey (1999) find stabilization effects from the adoption of deposit insurance. Anginer et al. (2013) find that bank risk is lower during a crisis in countries with deposit insurance.

However, deposit insurance may have adverse consequences, as it may encourage excessive risk-taking behavior, which might offset any stabilization benefits (Barth et al., 
2004). There is also sizable agreement in the literature that deposit insurance enhances moral hazard problems in the banking sector by incentivizing banks to take on excessive risk. When deposits are insured, however, bank depositors lack incentives to monitor (Demirgüç-Kunt and Huizinga, 2004; Ioannidou and Penas, 2010). The lack of market discipline leads to excessive risk taking, culminating in banking crises. Anginer et al., (2013), Demirgüç-Kunt and Detragiache (2002), Demirgüç-Kunt and Kane (2002), and Barth et al. (2004) find evidence in support of this view. Nonetheless, there is the argument that regulation and supervision can control the moral hazard problem by designing an appropriate insurance scheme. Therefore, we examine the relationship of deposit insurance with banks' returns and risk. During a crisis we expect banks to benefit from the presence of deposit insurance schemes. The hypotheses are stated as follows:

H5a: The presence of deposit insurance reduces bank risk during financial turmoil.

H5b: The presence of deposit insurance increases banks'stock returns during financial turmoil.

\section{A narrative of the credit and sovereign debt crises}

Over the period 2000 to 2007, banking activities over the world experienced rapid growth leading to an expansion of their balance sheets and therefore to an increase in their risk appetite. For instance, banks increasingly via financial innovation expanded into foreign currency assets such as US dollar-denominated claims, and European banks in particular showed the largest growth in foreign claims. Even though the exposures to the respective foreign currency claims were hedged off-balance sheet, this still led to an increase in funding risk, in which European banks had substantial funding needs of $\$ 1.1$ to $\$ 1.3$ trillion USD by mid-2007 (McGuire and von Peter, 2009). Similarly, Acharya and Schnabl (2009) argue that the global imbalances do not offer a valid explanation as to why the financial crisis spread internationally. Rather, they argue, it is the fact that large commercial banks in both current 
account surplus and deficit countries had large exposures to asset-backed commercial paper (ABCP) conduits (valued at $\$ 1.2$ trillion USD of short-term ABCP outstanding in June of 2007) that caused the financial crisis to spread so rapidly in 2007. Acharya and Schnabl (2009) also argue that it was the lax regulation monitoring the financial services industry that contributed to the financial crisis of 2007.

When the financial crisis started to unfold in 2007, this funding risk became more pronounced for banks, which had a significant impact in the markets such as FX and money markets. Moreover, European banks required the support of central banks in dealing with this associated risk until the end of September, 2008 (McGuire and von Peter, 2009). During 2008-09, there was limited concern regarding European sovereign debt, but the shockwaves of the 2007 financial crisis triggered a reevaluation of asset prices, risk, and growth prospects, especially in countries with economic imbalances (Lane, 2012). As shown in Figure 1, there is a significant increase in the market valuations relative to GDP leading up to the financial crisis. Once the financial crisis starts unfolding in 2007 , there is a significant decrease of market valuations relative to GDP. Accordingly, we use 2007-08 as the credit crisis period to measure risk and stock returns. In 2009 and 2010, the markets are recovering from the financial shock of 2007-08, when the sovereign debt crisis starts to take hold, leading to further reduction in market valuations across the board. We use 2011 to measure risk and return during the sovereign debt crisis. In 2012, though, there are signs of recovery, and in both crises, there is a significant decrease in market valuations, due to reevaluations of asset prices and factoring new potential risks (Lane, 2012), lasting more than a year and followed by a recovery.

[Insert Figure 1 here]

Figures 2 and 3 show the evolution of total loans outstanding and the respective annual changes that were given by banking institutions (domestic and foreign) in a set of EU 
countries and the US. The figures show that after 2004, the value of loans outstanding experiences a significant increase, reaching their peak in 2007 when the financial crisis erupts. Following the financial crisis, there is a small adjustment in the value of loans in 2008 and 2009, which increases again in 2010when the sovereign debt crisis starts. In the two years that follow the sovereign debt crisis, there is a small downward readjustment in the value of loans.

[Insert Figures 2 and 3 here]

After 2007, there is a constant growth in sovereign debt (Figure 4), resulting in a significant and abrupt rise in the yields of sovereign debt bonds in a number of countries in the European periphery. Following, there is a divergence for a number of European periphery countries in terms of sovereign bond yield spreads, starting in early 2010. Lane and MilesiFerretti (2012) find a relationship between high current account deficits over 2005-08 and significant current account reversals and expenditures over 2008-10. Toward the end of 2009 , there is an increase in the number of countries reporting large deficit-to-GDP ratios (Lane, 2012). Hui and Chang (2011) show that CDS spreads rose significantly to almost 250 bps in February 2010, which they surpass in the spring of the same year.

[Insert Figure 4 here]

\section{Variables used and methodology}

\subsection{Distance to default}

We use $\log z$, as introduced by Laeven and Levine (2009), to capture default risk. $\log \mathrm{z}$, which measures the distance from bankruptcy (Roy, 1952), is estimated as the average ROA plus the capital-to-asset ratio divided by the standard deviation of the ROA. A higher zscore indicates lower bank risk. We use the natural logarithm of $\mathrm{z}$-score in our regressions, because the distribution of z-score is highly skewed. 
Laeven and Levine (2009) show that the impact of the capital stringency index on the distance to default depends critically on the ownership structure. In widely held banks, a marginal increase in capital stringency has little impact on bank distance to default, while stronger capital stringency boosts bank risk when the bank has a powerful owner. The evidence is consistent with the view that capital regulations increase the risk-taking incentives of owners (Koehn and Santomero, 1980; Buser, Chen and Kane, 1981). In the absence of a powerful owner the stringency of capital regulations has little marginal influence on risk. Beltratti and Stultz (2012) assess the log of distance to default in the credit crisis and report that banks with higher ownership by the controlling shareholder have a lower distance to default. In addition, banks with a more shareholder-friendly board have a lower distance to default. Finally, the index of capital regulation has a positive coefficient, while the current account, the index of powers of the supervisors, the index of private monitoring, and the deposit insurance variable all have a negative coefficient. Our focus in this paper is to assess whether regulations are effective when a crisis hits the banking sector. We estimate the following equation with $\log \mathrm{z}$ calculated during the credit and the sovereign debt crises.

$$
\begin{aligned}
\log _{i, j, \text { Crisis }_{i}=\alpha} & \beta_{1} \text { Offical }_{i, j}+\beta_{2} \text { Capital }_{i, j}+\beta_{3} \operatorname{Re}_{\text {strict }}{ }_{i, j}+\beta_{4} \text { Private }_{i, j} \\
& +\beta_{5} \text { DepositInsurance }_{i, j}+\Omega \text { Bank and Country controls }_{i, j, t-1}+\varepsilon_{i, j, t} \ldots
\end{aligned}
$$

$\log \mathrm{z}_{i, j, c r i s i s}$ is $\log \mathrm{z}$ for bank $i$, in country $j$ during the credit and sovereign debt crises respectively. We calculate $\log z$ as the average ROA plus the capital-to-asset ratio divided by the standard deviation of ROA. For estimating $\log z$ during the credit crisis, we use the capital-to-assets ratio in 2008 and for ROA we use the average return on assets during 19982008 along with the standard deviation of ROA over the same period, as in Beltratti and Stutz (2012). For the sovereign debt crisis, the capital-to-assets ratio is taken at 2011 and for ROA we use the average return on assets during 2001-2011, along with the standard deviation of ROA over the same period. Official ${ }_{i, j}$ is a score that reflects the power of the commercial 
bank supervisory agency where bank $i$ is located in country $j$. Capital $l_{i, j}$ is a score that reflects the regulatory oversight of bank capital for bank $i$ in country $j$. Restrict ${ }_{i, j}$ is a score that measures the regulatory restrictions on the activities of banks where bank $i$ is located in country j. Private monitoring $i, j$ is a score that measures the degree of private monitoring where bank $i$ is located in country $j$. Deposit insurance ${ }_{i, j}$ is a dummy variable equal to one where there is explicit deposit insurance (Demirgüç-Kunt et al., 2007).

The explanatory regulation variables are retrieved from the World $\mathrm{Bank}^{3}$ as in Caprio et al. (2007, revised in June 2008), The banking regulations survey contains 312 questions on different dimensions, and most of the questions require yes/no types of answers. We form scores for measuring different dimensions, which are called official, capital, restrict, and private monitoring. All the bank-level and country-level controls are described in sections 4.6 and 4.7, respectively. Finally, we estimate equation (1) with ordinary least squares (OLS). We ensure that multicollinearity is not present by checking the correlation matrix and by estimating the variance inflation factor (VIF) following the estimation of our models. ${ }^{4}$

\subsection{Marginal expected shortfall}

The recent financial crisis has led to a reevaluation of risk taking and regulation of the financial system, with a transformed interest in systemic fragility and macro prudential regulation. This needs an effort to understand not only the risk of individual financial institutions but an individual bank's contribution to the risk of the financial system as a whole. Therefore, from a regulatory viewpoint, there is an increasing agreement that in safeguarding systemic stability, the link in the risk-taking behavior of banks is much more important than the absolute level of risk taking in any individual institution. As an alternative measure of bank-level risk, we compute a measure of each bank's contribution to the system

\footnotetext{
${ }^{3}$ This data set is taken from http://econ.worldbank.org/

${ }^{4} \mathrm{We}$ thank an anonymous referee for this suggestion.
} 
as a whole. Our measure of marginal expected shortfall is based on the expected capital shortfall framework, as in Acharya et al. (2012).

The systemic expected shortfall of an institution refers to the capital deficiency a financial firm would face in case of a systemic event. It is based on the idea that a shortage of capital is hazardous for the individual firm but becomes risky for the whole economy if it happens just when the rest of the banking sector is also undercapitalized. This measure is intended to capture how much each firm adds to the risk of the banking system as a whole. The MES of a firm is the expected loss an equity investor in a financial firm would experience if the market declined substantially. Following Acharya et al. (2010), we use MES as our systemic risk measure. MES measures the average firm return on days when the market as a whole is in the tail of its loss distribution:

$$
M E S_{t}^{i}=\frac{1}{T} \sum_{t=1}^{T}\left(R_{t}^{i} \mid R_{t}^{M}<\Gamma\right) \ldots \ldots . .(2)
$$

$R_{t}^{i}$ is the equity return of financial firm $i$, and $R_{t}^{M}$ is the market index return. A systemic event is defined as a drop of the market index below a threshold $\Gamma$, over a given time horizon. The systemic event is thus denoted by $R_{t}^{M}<\Gamma$.We estimate the MES by following Acharya et al. (2010) at a standard risk level of 5\%, using daily data for equity returns retrieved from DataStream. This means that we take the 5\% worst days for the market returns $\left(R_{t}^{M}\right)$ during the credit and sovereign debt crises and then compute the average return on any given firm $\left(R_{t}^{i}\right)$ for these days. Our main focus in this paper is whether regulations are effective when a crisis hits the banking sector. We estimate the same equation using MES as left-hand side variable calculated during the credit crisis and the Sovereign Debt crisis. 


$$
\begin{aligned}
\text { MES }_{i, j, \text { Crisis }}=\alpha+ & \beta_{1} \text { Offical }_{i, j}+\beta_{2} \text { Capital }_{i, j}+\beta_{3}{\text { Re } \text { strict }_{i, j}+\beta_{4} \text { Private }_{i, j}} \\
& +\beta_{5} \text { DepositInsurance }_{i, j}+\Omega \text { Bank and Country controls }_{i, j, t-1}+\varepsilon_{i, j, t}
\end{aligned}
$$

$\mathrm{MES}_{i, j, \text { crisis }}$ is the marginal expected shortfall for bank $i$, in country $j$ during the credit and sovereign debt crises respectively. We calculate MES, using equation 2 above, for the credit crisis from June 2007 to December 2008 to measure banks' systemic risk, as in Fahlenbrach et al. (2012) and Beltratti and Stulz, (2012). For the sovereign debt crisis, we calculate MES from May 2011 to December 2011 to measure banks' systemic risk during that period. In the robustness section, we use two alternative time period to calculate systemic risk during the sovereign debt crisis. Finally, we use the same explanatory variables and econometric procedure as in section 4.1 .

\subsection{Idiosyncratic risk}

We analyze idiosyncratic risk as a measure of business/operational risk of banks as in Kane and Unal (1988) and Flannery and James (1984). Recently, after being hit by the financial crisis, there was a significant increase in interest in idiosyncratic risks of banks. For instance, Hoque (2013) reports a positive relationship between idiosyncratic risk and bank capital during the credit crisis and a negative relationship during the sovereign debt crisis. Beltratti and Stultz (2012) find a negative relationship between idiosyncratic risk and bank capital and a positive relationship between ownership and idiosyncratic risk. Anginer et al. (2013) show that deposit insurance is positively associated with risk taking in the pre-crisis period and negatively associated with risk taking in the crisis period. Idiosyncratic is the idiosyncratic volatility, which is the annualized standard deviation from the market model regression residuals that estimate beta. We assess whether regulations are effective when a crisis hits the banking sector. We estimate the same equation twice using idiosyncratic risk as the left-hand side variable calculated for the credit crisis and the sovereign debt crisis. 


$$
\begin{array}{r}
\text { Idiosyncratic Risk }_{i, j, \text { Crisis }}=\alpha+\beta_{1} \text { Offical }_{i, j}+\beta_{2} \text { Capital }_{i, j}+\beta_{3} \operatorname{Re}_{\text {strict }}{ }_{i, j}+\beta_{4} \text { Private }_{i, j} \\
+\beta_{5} \text { DepositInsurance }_{i, j}+\Omega \text { Bank and Countrycontrols }_{i, j, t-1}+\varepsilon_{i, j, t}
\end{array}
$$

Idiosyncratic risk $k_{i, j, c r i s i s}$ is the annualized residual risk for bank $i$, in country $j$ for the credit and sovereign debt crises respectively. For the credit crisis, we calculate idiosyncratic risk from the one-factor market model regression residuals by using banks' stock returns and the MSCI World Index returns, as a proxy for the market portfolio, over June 2007 to December 2008, as in Fahlenbrach et al. (2012) and Beltratti and Stulz (2012). For the sovereign debt crisis, we calculate the idiosyncratic risk from the one factor market model regression residuals by using banks' stock returns and the MSCI World Index returns, as a proxy for the market portfolio, from May 2011 to December 2011. In the robustness section, we use two alternative time periods to calculate idiosyncratic risk during the sovereign debt crisis. Finally, we use the same explanatory variables and econometric procedure as in section 4.1

\subsection{Systematic risk}

We analyze systematic risk as a measure of banks' market risk, as in Kane and Unal (1988) and Flannery and James (1984). A higher sensitivity of bank share prices with market indices during both crises leads us to examine what factors drive market risk. Haq and Heaney (2012) analyze the systematic risk of banks in European countries and find that systematic risk is negatively related to bank capital, size, and charter value. Our systematic risk measure, Beta, is the beta coefficient estimated based on the one-factor model (CAPM) by regressing individual banks' stock returns against the MSCI World Index returns. We analyze whether regulations affect systematic risk when a crisis hits the banking sector. We estimate the same equation twice, using Beta as the left-hand side variable calculated during the credit crisis and the sovereign debt crisis. 


$$
\begin{aligned}
\text { Beta }_{i, j, \text { Crisis }}=\alpha+ & \beta_{1} \text { Offical }_{i, j}+\beta_{2} \text { Capital }_{i, j}+\beta_{3}{\text { Re } \text { strict }_{i, j}+\beta_{4} \text { Private }_{i, j}} \\
& +\beta_{5} \text { DepositInsurance }_{i, j}+\Omega \text { Bank and Country controls }_{i, j, t-1}+\varepsilon_{i, j, t} \ldots
\end{aligned}
$$

Beta $_{, i j, \text { crisis }}$ is the measure of systematic risk for bank $i$, in country $j$ for the credit and sovereign debt crises, respectively. For the credit crisis, we estimate beta by employing onefactor market model regressions from June 2007 to December 2008, as in Fahlenbrach et al., (2012) and Beltratti and Stulz, 2012). For the sovereign debt crisis, we estimate beta by employing one-factor market model regressions over May 2011 to December 2011 . We use the MSCI World Index returns as the proxy for market returns. In the robustness section, we use two alternative time period for estimating beta during the sovereign debt crisis. Finally, we use the same explanatory variables and econometric procedure as in section 4.1.

\subsection{Buy and hold abnormal returns (BHAR)}

Since the late 1990's, there has been a growing shift in the view of the importance of market variables on the risk assessment of banks and how these variables can enhance supervisory monitoring (Greenspan, 1998;Curry et al. 2001, 2003). Moreover, bank supervisors assess a bank's risk through their proprietary information gathered at infrequent intervals. Berger et al. (2000) suggest that market data are not only informative but that they can also contain information not yet incorporated into supervisors' information, while market data do not fully reflect all the information that is available to supervisors. Since market variables contain information on firm risk reflected in the daily price changes, supervisory assessment can be complemented via the equity markets (Gunther et al., 2001; Hall et al., 2001; Elmer and Fissel, 2001; Curry et al., 2001). Krainer et al. (2001, 2003) also show that cumulative abnormal returns are able to anticipate changes to banks' risk captured by credit ratings. Moreover, the authors argue that equity market variables add value to regulators' assessment of banks and in a timely manner. 
As in Krishnan et al. (2005), banks' stock market performance contains supplementary information regarding banks' risk, which is also reflected in a timely manner. Based on the learning hypothesis, banks that learn from a past bad experience will adjust their risk attitude (Fahlenbrach et al., 2012). In turn, the shift in banks' risk attitude should be reflected in their stock performance. Therefore, as in Belttrati and Stulz (2012) and Fahlenbrach et al. (2012), we estimate banks' buy-and-hold abnormal returns to assess what drives their performance and whether supervision regulations and any capital measures affect banks' risk as reflected in their stock price.

To measure stock market performance, we calculate the BHAR following Beltratti and Stulz (2012), as follows:

$$
B H A R_{i, j, c r i s i s}=\prod_{t=1}^{T}\left(1+R_{i, j, c r i s i s}\right)-\prod_{t=1}^{T}\left(1+R_{M, t, c r i s i s}\right) \ldots \ldots \ldots .(6) \text { ? }
$$

Where $B H A R_{i, j, c r i s i s}$ is the buy-and-hold abnormal return for bank $i$ in country $j$ during a crisis period, $R_{i, j, c r i s i s}$ is the daily return of bank $i$ in country $j$, and $R_{M, j, c r i s i s}$ is the daily return on the market proxied by the MSCI World Index return. Then, we estimate the following equation twice, using BHAR as the left hand side variable calculated during the credit and sovereign debt crises.

$$
\begin{aligned}
\text { BHAR }_{i, j, \text { Crisis }}=\alpha+ & \beta_{1} \text { Offical }_{i, j}+\beta_{2} \text { Capital }_{i, j}+\beta_{3}{\text { Re } \text { strict }_{i, j}+\beta_{4} \text { Private }_{i, j}} \\
& +\beta_{5} \text { DepositInsurance }_{i, j}+\Omega \text { Bank and Country controls }_{i, j, t-1}+\varepsilon_{i, j, t} \ldots(7)
\end{aligned}
$$

We calculate BHAR from June 2007 to December 2008 to measure banks' share price performance. Even though the credit crisis did not officially end at the end of 2008, since it continued through the first few months in 2009 , the fall in share prices at the beginning of 2009 may have been partly due to bank rescues. Moreover, we use December 31, 2008, as a cut-off point to be consistent with Fahlenbrach et al. (2012) and Beltratti and Stulz (2012). 
We calculate the BHAR from May 2011 to December 2011 to measure banks' share price performance during the sovereign debt crisis. In the robustness section, we use two alternative period definitions to calculate risk and return during the sovereign debt crisis. We use the same explanatory variables and econometric procedure as in section 4.1.

\subsection{Bank-level controls}

To understand the importance of bank capital during times of turmoil, we use Tier I capital, which is a measure of capital adequacy, following Laeven and Levine (2009), and which was more relevant during the crisis, according to Demirgüç-Kunt et al. (2010). Tier 1 capital is defined as shareholder funds plus perpetual noncumulative preference shares relative to risk-weighted assets and off-balance sheet risks, measured under the Basel rules. This figure is expressed as a percentage and should be at least $4 \%$. Banks with greater quality capital are more able to absorb losses during financial turmoil (Beltratti and Stultz, 2012). Therefore, investors attach great importance to a bank's capital quality, and we expect a positive relationship between bank capital and risk.

To shed light on the impact of liability structures, we use deposits, defined as total deposits relative to total assets (Anginer et al., 2013). With explicit deposit insurance in place, deposit financing is not subject to runs. However, other money market-related funding is subject to runs (Adrian and Shin, 2010; Gorton, 2010) and dries up during crisis times. Therefore, we use funding fragility, introduced by Demirgüç-Kunt and Huizinga (2010), defined as the ratio of deposits from other banks, other deposits, and short-term borrowing to total deposits plus money market and short-term funding. We expect banks with more deposits and less funding fragility to take more risk.

To capture the asset side of the balance sheet, we use several measures. The major asset of any type of commercial, mortgage, and cooperative bank is loans. Loans include residential mortgage loans, other mortgage loans, other consumer or retail loans, corporate $\&$ 
commercial loans, and other loans minus reserve against possible losses on impaired or nonperforming loans. Banks with more loans on their books are more likely to have relatively lower exposure to off-balance sheet securities (e.g., derivatives), and thus run a lower risk with the widening of the credit spreads during a crisis (Beltratti and Stultz, 2012). Therefore, banks with higher loans rather than risky securities should perform better, ceteris paribus. However, because we do not have the composition of loans as such, we do not have an expectation of the sign of loans. Following Laeven and Levine (2009), we use liquidity, defined as liquid assets scaled by total assets. As banks with more liquid assets are expected to perform better during a crisis, we expect a positive relationship between liquidity and stock performance.

To capture the income statement exposure, we use income diversity. Banks that derive their income from diverse activities have less exposure during a crisis. We use income diversity, by following Laeven and Levine (2008), defined as the absolute value of difference between net interest income and other operating income divided by total operating income.

\subsection{Country-level governance and macroeconomic variables}

We include macroeconomic variables as additional controls. For instance, countries with a higher level of financial development and economic fundamentals might have different risk and returns. To control for country-level development, we use the gross domestic product (GDP) per capita at 2006 constant terms, as in Anginer et al. (2013). To control for the financial position of the country, we use current account balance, as in Klomp and Haan (2012). Current acc. bal. is the current account balance divided by GDP. To control for level of market competition, we use concentration, as in Laeven and Levine (2009).Concentration is the total assets of the largest three banks in each country divided by total banking assets.

Evidence shows that companies in countries with better country-level governance have better returns, as shareholders' rights are better protected (John et al., 2008). ADRI is La 
Porta et al.'s (1998) anti-director index as revised by Djankov et al. (2008). A higher value means better protected shareholder rights. The variable institution is used, following Klomp and Haan (2012). It is the arithmetic average of six indicators called voice, political stability, government effectiveness, regulatory quality, rule of law, and corruption that are reported in Kaufmann et al. (2008). A higher value for an institution means that better and more efficient supervisory institutions are present.

\section{Data and descriptive statistics}

\subsection{Descriptive statistics}

We collected bank data from Bankscope. We searched for the largest 1,000 banks in Bankscope by asset size at the end of 2006 . Included in the sample are commercial banks, savings banks, cooperative banks, and mortgage banks. When we selected the largest 1,000 banks, Bankscope provided both listed and unlisted banks, with a total of 502 unlisted banks. Since we focused on listed-only banks, this reduced the number of banks to a significant extent. Moreover, as we assessed the impact of regulations on global banks in the credit and sovereign debt crisis, we employed those banks listed during the credit crisis and the sovereign debt crisis. In total, 120 banks were delisted following the credit crisis. In addition, as we required bank balance sheet and income statement data for 2006 and 2010, we excluded the delisted banks, as data was not available in Bankscope. Our final sample included 378 global banks. We retained 378 banks for which we had accounting and share price data. All the systematically important banks (29) are included in the sample. ${ }^{6}$ Finally,

\footnotetext{
${ }^{6}$ The list of Globally Systemically Important Financial Institutions is very much as had been expected, with 17 European banks, eight US ones, three Japanese, and one Chinese: Bank of America,Bank of China,Bank of New York Mellon, Banque Populaire CE, Barclays,BNP Paribas, Citigroup, Commerzbank, Credit Suisse, Deutsche Bank, Dexia, Goldman Sachs, Crédit Agricole, HSBC, ING Bank, JP Morgan Chase, Lloyds Banking Group, Mitsubishi UFJ FG, Mizuho FG, Morgan Stanley, Nordea, Royal Bank of Scotland, Santander, Société Générale, State Street, Sumitomo Mitsui, UBS, Unicredit Group, and Wells Fargo. The FSB and the Basel Committee of Banking Supervision drew up a list of G-SIFIs based on five
} 
we downloaded data on share prices and the MSCI World Index from DataStream; all data is in US dollars.

Table 1 provides the descriptive statistics. The mean (median) distance to default is 3.106 (2.965) during the credit crisis. The distance to default is higher during the credit crisis and significantly different than in the sovereign debt crisis. Our measure for systemic risk, MES, is lower during the credit crisis. The mean (median) difference test shows a significant difference between the credit crisis and the sovereign debt crisis. Systematic risk, as measured by beta, was lower during the credit crisis as compared to the sovereign debt crisis. It seems to increase after the $2007-08$ credit crisis. Idiosyncratic volatility shows a similar picture, as it is higher before the 2011 crisis. The 2007-08 credit crisis contributed to the systematic and idiosyncratic volatility. The mean (median) BHAR2007-08 during the credit crisis is $-0.502(-0.571)$, which shows that banks perform poorly. BHAR2011 is also negative and shows that banks perform badly during the sovereign debt crisis as well.

[Insert Table 1 here]

All the accounting variables are calculated before the crisis. Tangible equity does not show any significant difference between these two periods. Average Tier I capital shows that banks increase regulatory capital significantly before the 2011 crisis period, in order to gradually comply with the new capital requirements introduced in Basel III. Liquid assets are significantly higher before the 2007-08 crisis than in 2011 . There is no significant difference in the deposit ratios of the banks during those periods. Funding fragility is higher before the credit crisis compared to the sovereign debt crisis. The results give an early indication that in the aftermath of the 2007-08 credit crisis, banks strive to strengthen their positions by reducing their funding fragility. The loan to total asset ratio is slightly higher before 2011.

criteria: their absolute size, their complexity, the extent of their cross-border activity, and the degree to which they are interconnected with the rest of the financial system. 
Even though the per-capita GDP is the same during both crisis periods, the current account balance as a percentage of GDP deteriorates during the sovereign debt crisis.

All the regulations variables show a good degree of variability. The $5^{\text {th }}$ percentile for official supervisory power is 7 , and the $95^{\text {th }}$ percentile is 13 . Capital restrictions are bounded between 4 and 8 . The country-level variables show a wide variety of regulation levels. For instance, concentration shows a minimum of 0.32 and a maximum of 0.85 . Eighty-four percent of our sample banks have explicit deposit insurance. In sum, there is a lot of variation in the regulation levels, which makes it possible to test our conjectures.

\subsection{Cross-country variations}

Table 2 provides the descriptive statistics for the risk and return characteristics of banks across countries. In particular, we report cross-country variations for countries that have at least five banks in the sample. Banks in Poland have the highest distance to default $(\log \mathrm{z})$ measure during the credit crisis, but this changes during the sovereign debt crisis, as banks in Poland become more vulnerable to sovereign debt exposure and uncertainty. We find that Chilean banks have the highest systemic risk, as the MES is the lowest for these two countries during both the credit and sovereign debt crises. Banks in Austria have the lowest idiosyncratic risk in both the credit (18.41) and the sovereign debt (27.34) crises. In contrast, banks in Indonesia have the highest idiosyncratic risk during both crisis periods. With regard to beta, banks in Switzerland and the US have the highest beta values for both crisis periods (beta2007:1.48, beta2011:1.67 for Switzerland and beta2007:1.45, beta 2011:1.78 for the US, respectively).Moreover, the banks based in Japan have the lowest beta during the credit crisis (0.67), and this remains low during the sovereign debt crisis (0.86). The lowest BHAR is reported for Greece during both the credit $(-0.759)$ and the sovereign debt $(-0.902)$ crises. Banks in Japan perform relatively better during both crisis periods (BHAR is -0.230 in 200708 and 0.003 in 2011). 


\section{Empirical results}

\subsection{Impact of regulations on risk and return during the credit crisis}

This section presents the results on bank risk and returns during the credit crisis. In particular, we assess the impact of a number of regulations, while controlling for bankspecific characteristics, on four measurements of bank risk and the buy-and-hold returns during the credit crisis.

\subsubsection{Distance to default}

We first examine whether the regulations have any impact on the distance to default, as introduced by Laeven and Levine (2009). Table 4, columns (1)-(2) report the regression results, with distance to default $(\log \mathrm{z})$ as the dependent variable. The results for the credit crisis show that restriction, private monitoring, and deposit insurance are negatively and significantly related to the distance to default. These results imply that the restrictions imposed on bank activities do not increase the soundness of the banks when a crisis breaks out. Due to moral hazard issues, banks may engage in risky activities if they are allowed to conduct any activities (Boyd et al., 1993). However, we find that restricting bank activities is negatively associated with bank soundness, consistent with Barth et al. (2004) and Beltratti and Stultz (2012). According to Demirgüç-Kunt and Detragiache (2002), deposit insurance could influence bank soundness in two opposite ways. Firstly, if deposit insurance is in place, it increases bank soundness by reducing the chances of bank runs. In contrast, banks may engage in excessive risk-taking behavior. Our results here highlight the second view. In the presence of deposit insurance, banks are less sound amidst financial turmoil. Our results are consistent with Barth et al. (2004) and Demirgüç-Kunt and Detragiache (2002), who show that the presence of an explicit deposit insurance scheme tends to increase the probability of banking crises. 
[Insert Table 3 here]

In column (2), we include buy-and-hold returns before the credit crisis, Tier 1 capital, funding fragility, loans, income diversity, log of assets, GDP per capita, current account balance, and concentration of banking sector. We find that our main results in terms of regulations survive after controlling for other variables. We include BHAR to test whether the market provides any information on bank soundness, but we find no such evidence. We include Tier 1 capital to test whether better capitalized banks are sounder, and we find it is strongly and positively related to bank soundness. However, this is in contrast to Beltratti and Stultz (2012). We find that size is negatively related to distance to default, which implies that larger banks are less safe. Finally, concentration is significantly positively related to bank soundness.

\subsubsection{Systemic risk}

From a regulatory viewpoint, there is increasing consensus that the correlation in the risk-taking behavior of banks is much more relevant than the absolute level of risk taking in any individual institution. The financial crisis of 2007-08 highlighted the importance of systemic risk leading regulators to focus more on preventing future financial crises from spreading through the financial system, e.g., the ongoing work by the Basel Committee and the Financial Stability Board, striving to set new regulatory requirements for Systemically Important Financial Institutions (SIFI). Acharya (2009) suggests that if sovereign states or central banks provide an implicit guarantee to cover losses stemming from a systemic crisis, banks will have more incentives to take on correlated risks. Guaranteed banks will not have any incentives to diversify their operations, as they are protected by the guarantees.

According to Anginer et al. (2013), deposit insurance not only increases bank-level risk taking through the standard moral hazard channel, but it may also increase risk-taking on the whole as well. The use of individual banks' contribution to systemic risk measure is 
relatively new and allows us to test the effects of regulations during the credit crisis and sovereign debt crisis. Most of the earlier empirical work has examined the relationship between regulation and systemic stability by using the incidence of banking crisis at the country level as a measure of systemic risk (e.g., Demirgüç-Kunt and Detragiache, 2002).

In this section, we examine the relationship between regulations and bank-level systemic risk during the credit crisis. The regression specifications and control variables are the same as those used in Section 6.1.1. We use marginal expected shortfall as the dependent variable to measure banks' systemic risk, as described in Section 4. The results are in columns (3)-(4) in Table 3. The results show that capital regulation and activity restrictions are positively related to systemic risk during the credit crisis. This suggests that better oversight of capital is related to higher MES, which means lower systemic risk, consistent with Fernandez and Gonzalez (2005), who report that stringent capital requirements reduce banking risk. Moreover, higher activity restrictions reduce individual banks' contribution towards systemic risk. The results also show that deposit insurance is negatively related to MES, implying that in the presence of deposit insurance, banks take more risk, which increases the chance of bank runs. These results are consistent with Barth et al. (2004) and Demirgüç-Kunt and Detragiache (2002), who find that explicit deposit insurance increases the probability of banking crises. When we introduce bank- and country-level control variables (column (4), Table 3) most of the results related to regulations survive. None of the control variables is significant. In this specification, private monitoring is positively related to MES, implying that higher private monitoring leads to higher MES. In other words, higher private monitoring reduces individual banks' contribution towards systemic risk.

\subsubsection{Idiosyncratic risk}

Next we examine the impact of regulations on idiosyncratic volatility. The regression specifications and control variables are the same as those used in Section 6.1.1, and we use 
idiosyncratic volatility as the dependent variable to measure banks' business risk, as described in Section 4. The results are in columns (5)-(6) in Table 3. The results in column (5), i.e., without bank- and country-level controls, show that official power and deposit insurance is positively and capital and restrictions are negatively related to idiosyncratic risk. The results show that higher capital restrictions lower the idiosyncratic risk, which is consistent with Fernandez and Gonzalez (2005). In the presence of deposit insurance, banks take more risks, as deposit insurance is positively related to idiosyncratic risk, consistent with Beltratti and Stultz (2012) and Anginer et al. (2013). Our results support the moral hazard channel of risk taking in the presence of deposit insurance.

We then introduce the bank- and country-level control variables in column (6). The results with respect to the regulations are mostly the same, with the exception that restriction is no longer significant. We include BHAR before the crisis and find that it is positive and significant. This suggests that banks with high returns before the crisis have higher risk during the crisis. The market imposes some discipline in terms of returns, which leads banks to take more risk. Moreover, the higher the funding fragility the lower the risk, as before the credit crisis, the short-term funding market is working well. Finally, larger banks take more risks as the log of assets is positively related to idiosyncratic risk.

\subsubsection{Systematic risk}

In this section, we examine the impact of regulations on banks' systematic risk. Therefore, we use banks' beta as the dependent variable, as described in Section 4, along with the same regression specifications and control variables as those in Section 6.1.1. The results are in columns (7)-(8) in Table 3. The results in column (7), excluding bank- and countrylevel variables, show that official supervision is positively related to banks' market risk. This is puzzling, as one would expect higher official supervision to prevent banks from taking excessive risks, hence resulting in lower market risk. In contrast, and as expected, we find 
that capital restrictions and private monitoring are negatively related to market risk. This finding, which is consistent with Fernandez and Gonzalez (2005), suggests that more stringent capital regulations and private monitoring prevent banks from taking excessive risk, resulting in their increased ability to absorb losses and be less sensitive to systematic risk. Moreover, we do not find any evidence that deposit insurance affects banks' systematic risk.

We then introduce the bank- and country-level controls, and our results on the impact of regulations remain the same. We also introduce BHAR to test whether there is any feedback through the market returns on beta, and we find that BHAR is highly significant and positive. This suggests that banks with high BHAR before the credit crisis are more sensitive to systematic risk during the crisis. In addition, we find that larger banks have higher beta, which shows the systemic importance of large banks in their respective stock markets. Finally, GDP per capita is positively related while current account balance is negatively related to beta.

\subsubsection{Buy-and-hold-returns}

In this section, we assess the drivers of banks' stock market performance during the two crises. The results on the stock market performance during the credit crisis, reported in Table 4, show that official supervision is consistently positive and highly significant. This suggests that the markets show greater confidence in the banking sector in countries with better and more effective official monitoring and that banks in these countries are more resilient during the credit crisis. This is also supported by the fact that regulatory restrictions are positive and significant, suggesting that in countries with stricter regulations, banks have a better stock market performance. This suggests that better official monitoring helps keep banks' ultimate owners' interests aligned with those of shareholders, resulting in a better stock performance during the crisis.

[Insert Table 4 here] 
The results on private monitoring are positive and significant. Based on the argument of Belttrati and Stulz (2012), that better governance has a positive effect on bank stock performance, our results on private monitoring suggest that better external monitoring leads to better bank governance. This, in turn, leads to better stock performance. We find that capital requirements have no impact on the market valuation and pricing of bank risk. We also find some evidence, though not as strong, that banks with higher Tier 1 capital perform better, consistent with Beltratti and Stulz (2012). The results also show that banks in countries with deposit insurance perform better. Further, we find that banks with greater idiosyncratic volatility and systematic risk show a poor performance during the credit crisis, consistent with Acharya et al. (2010) and Beltratti and Stulz (2012), who find a negative relationship between beta and returns during the credit crisis. We find no evidence of funding fragility, liquidity, or ratio of deposits having an impact on banks' stock performance. We do find, though, that banks with a lower ratio of loans over assets operating in countries with slowing economies have a poor stock performance during the credit crisis. We also find some evidence that banks in countries with higher current account balances have better stock performance, consistent with Lane (2012), who argues that the 2007 financial shock caused a reevaluation of asset prices, especially in countries with greater economic imbalances.

\subsection{Impact of regulations on risk and return during the sovereign debt crisis}

In this section we repeat the regressions on the same risk variables and the buy-andhold returns during the sovereign debt crisis. The objective here is to assess whether banks take more sensible risks in the aftermath of the credit crisis, and whether the regulations during the sovereign debt crisis affect banks' risk and returns the same way as in the credit crisis.

\subsubsection{Distance to default}


We examine whether regulations have any impact on the distance to default during the sovereign debt crisis, as in the credit crisis. This is particularly important, as after the credit crisis, a large number of banks went bankrupt. Table 5, in columns (1)-(2), reports the regression results for $\log \mathrm{z}$. In column (1), we only use the regulations variables. The results for the sovereign debt crisis show that as in the credit crisis, private monitoring is negatively and significantly related to the distance to default. Unlike the credit crisis, however, official supervision is negatively related to the distance to default. Deposit insurance is not significant in this regression. Our results for the sovereign debt crisis do not provide conclusive evidence for deposit insurance. We do not find support for Barth et al. (2004) and Demirgüç-Kunt and Detragiache (2002), who show that an explicit deposit insurance scheme tends to increase the probability of banking crises, as banks become less sound in the presence of a deposit insurance scheme.

\section{[Insert Table 5 here]}

In column (2), we include the bank- and country-level control variables. We find that restriction is negatively related to $\log z$, implying that the restrictions imposed on bank activities do not increase their soundness when a crisis breaks out. Due to moral hazard issues, banks may engage in risky activities if they are allowed to take any activities (Boyd et al., 1993). In contrast, we find that restricting bank activities is negatively associated with bank soundness, which is consistent with Barth et al. (2004) and Beltratti and Stultz (2012). We also include BHAR to test whether there is any market feedback on bank soundness in terms of returns. We find that BHAR is highly significant, suggesting that the market provides feedback regarding banks' soundness after the credit crisis and before the sovereign debt crisis. This implies that market participants become more vigilant to provide feedback once a crisis breaks out. We include Tier 1 capital to test whether better capitalized banks are sounder and find that Tier 1 capital is strongly and positively related to bank soundness, 
which is similar to the findings on the credit crisis. We do not find evidence of size being significantly related to the distance to default. Moreover, we find that GDP per capita is negatively related to distance to default, which shows that banks based in countries with higher GDP are more susceptible to risk. This is also consistent with the fact that the sovereign debt crisis essentially originates from European countries.

\subsubsection{Systemic risk}

In the aftermath of the financial crisis, systemic risk became more important, as regulators' objectives were to prevent another crisis. However, since after the credit crisis, sovereign states were drawn into the sovereign debt crisis via bank rescues, examining the correlated risk taking in the sovereign debt crisis can extend our understanding of the extent to which state or central bank guarantees can shake the base of the sovereigns. Acharya (2009) argues that banks are more likely to take on more correlated risks when there is an implicit state or central bank guarantee to cover losses stemming from a systemic crisis.

In this section, we examine the relationship between regulations and individual bank systemic risk during the sovereign debt crisis. The regression specifications and control variables are the same as those used in Section 6.1.2. As a dependent variable, we use marginal expected shortfall (MES), as described in Section 4, to proxy for the systemic risk. The results in Table 5, columns (3)-(4), show that capital regulation and activity restrictions are positively related, while deposit insurance is negatively related to systemic risk during the sovereign debt crisis, as they are during the credit crisis. This implies that better oversight of capital is related to lower systemic risk, as denoted by higher MES. Restricting banks' activity reduces individual banks' contribution toward systemic risk. In addition, deposit insurance is negatively related to MES, implying that in the presence of deposit insurance, banks take more risk. Consequently, this increases the likelihood of bank runs. Using previous banking crisis data, Barth et al. (2004) and Demirgüç-Kunt and Detragiache (2002) 
find that explicit deposit insurance increases the probability of banking crises. When we introduce bank- and country-level controls (Table 5, column (4)), most of the results related to regulations survive. None of the additional control variables are significant except ADRI. This suggests that in countries with better protected shareholder rights, banks experience less systemic risk.

\subsubsection{Idiosyncratic risk}

In this section, we assess the drivers of idiosyncratic risk during the sovereign debt crisis. The dependent variable is idiosyncratic volatility, and we use the same regression specifications and control variables as those used in Section 6.1.2. The results are shown in Table 5, columns (5)-(6). The results in column (5), excluding bank- and country-level control variables, show that higher capital restrictions lead to lower idiosyncratic risk, consistent with Fernandez and Gonzalez (2005). Moreover, we find that in the presence of deposit insurance, banks take more risk, even following the credit crisis, as deposit insurance is positively related to idiosyncratic risk during the sovereign debt crisis. As in the credit crisis, our results support the argument that the presence of deposit insurance increases moral hazard during the sovereign debt crisis. This is also consistent with Beltratti and Stultz (2012) and Anginer et al. (2013).

In column (6), we include the bank- and country-level control variables. Our previous results regarding the impact of regulation remain mostly the same. The only exception is regulatory restriction, which is no longer significant. Moreover, the results show that a higher level of private monitoring leads to higher idiosyncratic risk. This suggests that even though investors monitor banks, they still entice banks to take more risks in the pursuit for higher returns. In addition, we find that the BHAR before the sovereign debt crisis is positive and significant. This suggests that banks delivering higher returns prior to the sovereign debt crisis end up being more exposed to idiosyncratic risk. We also find that having higher Tier 1 
capital reduces idiosyncratic risk. This shows that one of regulators' ways of making banks more resilient and able to absorb greater losses is successful, as suggested by the lower idiosyncratic risk. Moreover, the results show that banks with more diverse income have lower risk during the sovereign debt crisis. However, we find that unlike the credit crisis, funding fragility and size are not significant. We also find that current account balance is negative and significant, suggesting that countries that are more financially sound have greater flexibility to intervene and prevent a bank from becoming insolvent, as opposed to financially fragile states. Finally, we find that shareholder protection, captured by ADRI, is negatively related to idiosyncratic risk.

\subsubsection{Systematic risk}

In this section, we assess the impact of regulations on banks' market risk during the sovereign debt crisis. We use banks' beta, discussed in section 4, as the dependent variable, and we employ the same regression specifications and variables as in section 6.1.2. The results are reported in Table 5, columns (7)-(8). The results (column (7)) show that official supervision is positively and capital and private monitoring are negatively related to market risk. This suggests that stringent capital regulations reduce systematic risk, consistent with Fernandez and Gonzalez (2005). In addition, the results show that higher private monitoring leads to lower systematic risk, which is consistent with the view that private monitoring reduces the systematic risk of banks. However, we find no evidence of deposit insurance having an impact on banks' systematic risk during the sovereign debt crisis, similar to our findings on the credit crisis.

In column (7), we introduce the bank- and country-level controls. We find that the higher a bank's BHAR is before the sovereign debt crisis, the higher its systematic risk is when the sovereign debt crisis unfolds. While private monitoring leads banks to take on greater risk, at the same time, investors require more returns. In addition, larger banks have 
higher beta, which shows the systemic importance of large banks in their respective stock markets. GDP per capita is positively and current account balance is negatively related to beta. Finally, higher levels of shareholder protection lead to lower systematic risk.

\subsubsection{Buy-and-hold-returns}

We assess the drivers of banks' stock market performance during the sovereign debt crisis in order to evaluate whether there is a shift in the factors that affect banks' stock market performance during the credit crisis. The results reported in Table 6 show that the impact of capital requirements is still not significant, while official and private monitoring remain positive and significant during the sovereign debt crisis, as in the credit crisis. However, regulatory restrictions cease to influence banks' stock performance, while deposit insurance schemes are negative and significant during the sovereign debt crisis, as opposed to the credit crisis. This suggests that in the presence of deposit insurance, banks take more risk and perform worse. Moreover, the adoption of higher Tier 1 capital levels that were introduced during the credit crisis becomes positive and significant. This is contrary to Acharya and Schnabl (2009), who find a negative relationship between banks' capital and stock returns during August, 2007, but is consistent with Beltratti and Stulz (2012), who find a robust, positive relationship between Tier 1 capital and bank performance. This suggests that banks with stronger balance sheets show a stronger stock performance. Idiosyncratic risk remains negative and significant, though beta has no impact during the sovereign debt crisis. This is consistent with Beltratti and Stultz (2012), who find a negative relationship between banks' beta and their stock performance.

Unlike the credit crisis, during the sovereign debt crisis, banks that are more financially robust in terms of funding fragility and overall deposits have a stronger stock performance, consistent with Fahlenbrach and Stulz (2011) and Beltratti and Stulz (2012), while liquidity and bank loans have no impact during this period. The results on current 
account balance and concentration remain the same for the credit and sovereign debt crisis.

This suggests that greater country stability and less uncertainty about future growth prospects have a significant impact on bank performance during the sovereign debt crisis. Finally, we find that in countries with strong institutional and regulatory frameworks and better corporate governance, captured by ADRI and institution, banks show a stronger stock performance.

This supports the argument that better governance leads to better stock performance (Beltratti and Stulz, 2012).

\section{Robustness checks}

Following Fahlenbrach et al. (2012), we calculate the BHAR from June 2007 to December 2008 to measure the risk and return for the credit crisis. For the sovereign debt crisis, we measure the risk and the BHAR starting from May 2011 until the end of 2011 (BHAR=-28.34). We use May 2011 as the starting point, because in May 2011, the Eurozone and the International Monetary Fund (IMF) approved a $€ 78$ billion bailout for Portugal. For robustness checks, we use two alternative definitions, the beginning of 2010 until the end of $2011(\mathrm{BHAR}=-25.89)$ and May 2010 to December $2011(\mathrm{BHAR}=-23.61){ }^{7}$ To examine the robustness of our results, we run the regressions using alternative measures of risks and BHARs, i.e., the period from the beginning of 2010 to the end of 2011 and the period from May 2010 to the end of 2011.

The results on risk regressions are presented in Table 7. The results regarding MES show that irrespective of time periods, restriction is positively and private monitoring and deposit insurance are negatively related to MES. When we analyze idiosyncratic risk, we find that higher capital restrictions and private monitoring lower the idiosyncratic risk. The market

\footnotetext{
${ }^{7}$ We choose the beginning of 2010 as the starting point, as concern starts to build about all the heavily indebted countries in Europe - Portugal, Ireland, Greece, and Spain. Alternatively, we use May 2010 as a starting point, as on May 2, 2010 the Eurozone members and the IMF agree on a $€ 110$ billion bailout package to rescue Greece.
} 
risk regressions show that the higher the official power, the lower the beta. In the presence of deposit insurance, a higher beta is observed. BHAR is significant in idiosyncratic risk and beta regressions. Likewise, Tier I capital is significant in idiosyncratic and beta regressions. We also find that the higher the size, the lower the idiosyncratic and market risk. Overall, the results found in Table 7 are similar to previous results.

The official power of the regulators is significant in all the regressions, implying that banks perform better in countries with higher official power. Deposit insurance is negative and significant, suggesting that banks in the presence of deposit insurance take more risk and perform badly during the sovereign debt crisis. The effect of private monitoring on stock performance is positive and significant only for the BHAR of May 2010 to Dec 2011. We argue that this is probably due to the fact that the concerns regarding the servicing of sovereign debt in the European periphery are gathering momentum in February 2010, initiating a new cycle of uncertainty in the markets with the announcement of the first bailout package for Greece in early May, 2010, commanding greater scrutiny and monitoring of banks and their exposure to sovereign debt.

Overall, the results shown in Table 8 are similar to our previous results and interpretations regarding the factors that affect banks' stock performance during the sovereign debt crisis. For instance, the results on ADRI and institution remain positive and significant. Consistent with the argument of Beltratti and Stulz (2012), that a better alignment of bank insiders' and shareholders' interests results in better performance, our results show that better investor monitoring leads to better corporate governance, resulting to better stock performance. Moreover, the results on Tier 1 capital and deposits remain positive and significant, and funding fragility remains negative, suggesting that banks with greater reliance on deposit and more robust funding show a better stock performance during the sovereign debt crisis. This is consistent with Beltratti and Stulz (2012), Fahlenbrach and Stulz 
(2011), and Fahlenbrach et al. (2012). The results on bank and country risk show that banks with higher idiosyncratic risk, which are based in more fragile countries — captured by GDP per cap — have worse stock performance.

[Insert Tables 7 and 8 here]

Finally, since our sample contains only 378 banks, it is important to check whether outliers are driving our results. We perform median regressions where the sum of the absolute weighted deviations is minimized. The results are qualitatively the same, as reported by using the ordinary least squares. We conclude that our results are not driven by outliers. We do not present these results, for brevity, but they are available from the authors upon request.

\section{Conclusion}

The financial crisis that originated in the securitized debt market spread rapidly, affecting all financial institutions to a certain degree, leading to numerous bank rescues and bankruptcies across countries. What is more, according to some commentators, this ignited the sovereign debt crisis. Even though our goal is not the identification of the reasons leading to the financial and sovereign debt crises, the poor bank performance in terms of risk and stock returns during both crises can be a good testing ground for regulation effectiveness. Hence, we shed light on the impact of regulations and regulatory and institutional frameworks.

In particular, we analyze whether regulations are effective for bank risk and returns across the world during the credit and sovereign debt crisis periods. The results show that greater official supervision leads to higher systematic risk in banks during both crises. Moreover, official supervision leads to banks being riskier, captured by distance to default, but only during the sovereign debt crisis. We also find evidence that greater capital leads to lower bank risk during both crises, suggesting that banks having enough capital can insulate themselves from financial turmoil. Regarding regulatory restriction, we find that it has no impact on insulating banks during both crises. But we find that restriction leads to better 
stock performance, but only during the credit crisis. Moreover, we find that having a deposit insurance scheme in place increases moral hazard and induces banks to take greater risks, resulting in greater exposure during both crises. Additionally, we find that greater private monitoring leads to lower bank risk. This suggests that investors actively monitoring banks prevent them from taking excessive risks. Hence, countries with higher private monitoring show a better stock performance during both crises.

Our results have several policy implications regarding the effectiveness and design of regulations to better control risk and thus enhance the performance of global banks which are the focal point of regulators. More restrictions on banks increase the stability of global banks and reduce the systemic risk and idiosyncratic risk during the credit crisis. Moreover, restrictions on bank activities seem to be effective for controlling the stability of banks during times of turmoil. However, Barth et al. (2013) show that restrictions reduce efficiency. Hence, policymakers should strive to find the right balance of restrictions for reducing systemic risk without decreasing efficiency. In line with Anginer et al. (2013) we find that deposit insurance is negatively related to bank stability and systemic risk, suggesting that deposit insurance increases moral hazard. This is also consistent with Hovakimian et al. (2003) and Laeven (2002) who show that under weak institutional environments deposit insurance may work detrimentally. Demirguc-Kunt and Kane (2002) also show that a country's private and public contracting environment is important in deposit-insurance adoption and design .Our findings raise the question: should policy makers rethink the design of deposit insurance as it increases the instability and systemic risk of individual banks?

In terms of returns, banks in countries with greater official power, restrictions and private monitoring performed better during the credit crisis. These results suggest that while regulatory restrictions and supervision are necessary, at the same time it is important to have better private monitoring. Hence private monitoring, which is a market mechanism to reward 
better banks, complements regulatory supervision. Our findings also highlight the need for regulators to access market information in regular intervals to supplement other sources of regulatory information. While official power of supervisors and private monitoring still explain the stock return performance of banks during the sovereign debt crisis, imposing greater restrictions on bank activities does not enhance bank returns. Policymakers need to bear this in mind especially when planning to impose more restrictions on banks while the banking system is still fragile. The results reported in this paper are consistent with the World Bank regulations IV in Barth et al. (2013) who find that some countries have eased the restrictions following the global financial crisis.

Moreover, the evidence show that higher official power increases risk-taking during the credit crisis. This is consistent with the rent seeking view of supervisors as they use power to benefit favored voters, attract donations, and extract bribes (Shleifer and Vishny, 1998; Djankov et al., 2002; and Quintyn and Taylor, 2002). Beck et al. (2006) point out that if bank supervisory agencies have the authority to discipline noncompliant banks, the supervisors might use this power to induce or force banks to allocate credit so as to generate private or political benefits. Our findings raise some concerns regarding the optimal supervisory power of bank regulators.

Most of the regulations were effective in controlling risk, apart from deposit insurance which has a detrimental effect on risk. Official power and private monitoring explains the returns during both the crises. Overall, our results can be extended to having policy implications: regulatory restrictions and supervision may be costly and difficult to enforce, but combined with the market's scrutiny, they reduce the systemic risk, insulate banks from financial distress, and enable banks to provide a stronger stock performance during a crisis. 
Appendix 1: Variable definitions

\begin{tabular}{|c|c|c|}
\hline Variables & Definitions & Reasons for Inclusion \\
\hline $\log z$ & $\begin{array}{l}\text { Average ROA plus capital to asset ratio, divided } \\
\text { by the standard deviation of ROA. }\end{array}$ & $\begin{array}{l}\text { To capture the riskiness of the bank (Laeven and } \\
\text { Levine, 2008). }\end{array}$ \\
\hline MES & $\begin{array}{l}\text { Average return on sample banks conditioned on } \\
5 \% \text { worse returns on the market. }\end{array}$ & $\begin{array}{l}\text { To measure the systemic risk of banks (Acharya et al., } \\
\text { 2010). }\end{array}$ \\
\hline Idiosyncratic & $\begin{array}{l}\text { Annualized standard deviation from regressing } \\
\text { weekly stock returns of individual stocks against } \\
\text { the MSCI World Index. }\end{array}$ & $\begin{array}{l}\text { To capture the riskiness of the bank (Acharya et al., } \\
\text { 2010). }\end{array}$ \\
\hline Beta & $\begin{array}{l}\text { Coefficient from regressing weekly stock returns } \\
\text { of individual stocks against the MSCI World } \\
\text { Index. }\end{array}$ & $\begin{array}{l}\text { To capture the riskiness of the bank (Acharya et al., } \\
\text { 2010). }\end{array}$ \\
\hline BHAR & $\begin{array}{l}\text { Buy-and-hold abnormal return for individual } \\
\text { banks. }\end{array}$ & $\begin{array}{l}\text { To measure the stock market performance (Beltratti } \\
\text { and Stultz, 2012). }\end{array}$ \\
\hline Official & $\begin{array}{l}\text { A score that reflects the power of the commercial } \\
\text { bank supervisory agency. }\end{array}$ & $\begin{array}{l}\text { To explain whether supervisory power can explain } \\
\text { banks' risk and returns during a crisis (Caprio, Laeven } \\
\text { and Levine,2007). }\end{array}$ \\
\hline Capital & $\begin{array}{l}\text { A score that reflects the regulatory oversight of } \\
\text { bank capital. }\end{array}$ & $\begin{array}{l}\text { To assess whether regulatory oversight of bank capital } \\
\text { can explain banks' risk and returns during a crisis } \\
\text { (Caprio, Laeven and Levine,2007). }\end{array}$ \\
\hline Restrictions & $\begin{array}{l}\text { A score that measures the regulatory restrictions on } \\
\text { the activities of banks. }\end{array}$ & $\begin{array}{l}\text { To measure the relationship between level of } \\
\text { restrictions and bank risk and returns during a crisis } \\
\text { (Caprio, Laeven and Levine, 2007). }\end{array}$ \\
\hline $\begin{array}{l}\text { Private } \\
\text { monitoring }\end{array}$ & $\begin{array}{l}\text { A score that measures the degree of private } \\
\text { monitoring. }\end{array}$ & $\begin{array}{l}\text { To analyze whether private monitoring can discipline } \\
\text { bank risk taking and hence returns (Caprio, Laeven and } \\
\text { Levine, 2007). }\end{array}$ \\
\hline $\begin{array}{l}\text { Deposit } \\
\text { insurance }\end{array}$ & $\begin{array}{l}\text { A binary variable equal to one where there is } \\
\text { explicit deposit insurance and zero otherwise. }\end{array}$ & $\begin{array}{l}\text { To better understand the role of deposit insurance in } \\
\text { turmoil times (Demirgüç-Kunt, Kane and Laeven, } \\
\text { 2007). }\end{array}$ \\
\hline Tier I capital & $\begin{array}{l}\text { Shareholder funds plus perpetual non-cumulative } \\
\text { preference shares as a percentage of risk-weighted } \\
\text { assets and off-balance sheet risks measured under } \\
\text { the Basel rules. }\end{array}$ & $\begin{array}{l}\text { To capture the importance of bank capital in times of } \\
\text { turmoil (Demirgüç-Kunt, Detragiache and Merrouche, } \\
\text { 2010). }\end{array}$ \\
\hline Deposits & Total deposits as a fraction of total assets. & $\begin{array}{l}\text { To assess the impact of liability structures (Fahlenbrach } \\
\text { et al., 2012). }\end{array}$ \\
\hline $\begin{array}{l}\text { Funding } \\
\text { fragility }\end{array}$ & $\begin{array}{l}\text { Ratio of deposits from other banks, other deposits, } \\
\text { and short-term borrowing to total deposits, plus } \\
\text { money market and short-term funding. }\end{array}$ & $\begin{array}{l}\text { To assess the impact of liability structures (Demirgüç- } \\
\text { Kunt and Huizinga, 2010). }\end{array}$ \\
\hline Loans & Total loans divided by total assets. & $\begin{array}{l}\text { To capture the asset side of the balance sheet } \\
\text { (Demirgüç-Kunt, Detragiache and Merrouche, 2010). }\end{array}$ \\
\hline Size & Natur & To control for bank size. \\
\hline Income diversity & $\begin{array}{l}\text { Absolute value of the difference between net } \\
\text { interest income and other operating income } \\
\text { divided by total operating income. }\end{array}$ & $\begin{array}{l}\text { To assess income diversity and how vulnerable a bank } \\
\text { is during a crisis (Laeven and Levine,2009). }\end{array}$ \\
\hline$G D P$ & GDP per capita at 2006 constant terms. & Beltratti and Stultz (2012). \\
\hline $\begin{array}{l}\text { Current acc. } \\
\text { bal. }\end{array}$ & Current account balance scaled by GDP. & Beltratti and Stultz (2012). \\
\hline Concentration & $\begin{array}{l}\text { The total assets of the largest three banks divided } \\
\text { by total bank assets. }\end{array}$ & $\begin{array}{l}\text { To control for competition (Demirgüç-Kunt and } \\
\text { Huizinga, 2010). }\end{array}$ \\
\hline Institution & $\begin{array}{l}\text { Arithmetic average of six indicators: voice, } \\
\text { political stability, government effectiveness, } \\
\text { regulatory quality, rule of law, and corruption. }\end{array}$ & $\begin{array}{l}\text { To control for country-level effects (Kaufmann, Kraay } \\
\text { and Mastruzzi, 2008). }\end{array}$ \\
\hline$A D R I$ & $\begin{array}{l}\text { The revised anti-director index of La Porta et al. } \\
\text { (1998). }\end{array}$ & $\begin{array}{l}\text { To control for regulatory and institutional frameworks } \\
\text { in each country (Djankov, La Porta, Lopez-de-Silanes } \\
\text { and Shleifer, 2008). }\end{array}$ \\
\hline
\end{tabular}




\section{References}

Acharya, V., Engle, R.F., Richardson, M., 2012. Capital shortfall: A new approach to ranking and regulating systemic risks. American Economic Review Papers and Proceedings, 59-64.

Acharya, V.V., Johnson, T.C., 2007. Insider trading in credit derivatives. Journal of Financial Economics 84, 110-141.

Acharya, V.V., Pedersen, L.H., Philippon, T., Richardson, M., 2010.Measuring systemic risk. Working paper, New York University.

Acharya, V.V., Schnabl, P., 2010. Do global banks spread global imbalances? The case of asset-backed commercial paper during the financial crisis of 2007-09. IMF Economic Review 58, 37-73.

Adrian, T., Shin, H.S., 2008.Liquidity and leverage. Journal of Financial Intermediation 19, $418-437$.

Anginer, D., Demirguc-Kunt, A., Zhu, M., 2013. How does deposit insurance affect bank risk? Evidence from the recent crisis. Journal of Banking and Finance, forthcoming.

Bank for International Settlement, 2011.Basel III: A global regulatory framework for more resilient banks and banking systems, December 2010 (rev June 2011).

Barth, J.R., Caprio, Jr., G., Levine, R., 2001. Banking systems around the globe: Do regulations and ownership affect performance and stability? In: Mishkin, F.S. (Ed.), Prudential Supervision: What Works and What Doesn't. Univ. of Chicago Press, pp. $31-88$.

Barth, J.R., Caprio, G., Levine, R., 2006. Rethinking Bank Regulation: Till Angels Govern. Cambridge University Press, Cambridge, UK.

Barth, J.R., Lin, C., Mac, Y., Seade, J., Song, F.M., 2013. Do bank regulation, supervision and monitoring enhance or impede bank efficiency? Journal of Banking \& Finance 37 2879-2892.

Barth, J.R., Caprio, Jr., G., Levine, T., 2004. Bank regulation and supervision: What works best? Journal of Financial Intermediation 13,205-248.

Beck, T., Demirguc-Kunt, A., Levine, R., 2006. Bank concentration, competition and crisis: First results. Journal of Banking and Finance 30, 1581-1603.

Beltratti, A., Stulz, R.M., 2012. Credit crisis around the globe: Why did some banks perform better? Journal of Financial Economics 105, 1-17. 
Berger, A., Davies, S., Flannery, M., 2000. Comparing market and supervisory assessments of bank performance: Who knows what when? Journal of Money, Credit, and Banking 32, 641-667.

Berger, A.N., Herring, R.J., Szegö, G.P., 1995. The role of capital in financial institutions. Journal of Banking and Finance 19, 257-276.

Besanko, D., Kanatas, G., 1996. The regulation of bank capital: Do capital standards promote bank safety? Journal of Financial Intermediation 5 (4), 160-183.

Blum, J., 1999. Do capital adequacy requirements reduce risks in banking? Journal of Banking and Finance 23, 755-771.

Boot, A.W.A., Thakor, A.V., 1993. Self-interested bank regulation. American Economic Review 83, 206-211.

Boyd, J.H., Chang, C., Smith, B.D., 1998. Moral hazard under commercial and universal banking. Journal of Money, Credit and Banking 30 (3.2), 426-468.

Cao, C., Yu, F., Zhong, Z., 2010. The information content of option-implied volatility for credit default swap valuation. Journal of Financial Markets 13, 321-343.

Caprio, G., Laeven, L., Levine, R., 2007. Governance and bank valuation. Journal of Financial Intermediation 16, 584-617.

Cheng, I.-H., Hong, H., Scheinkman, J.A., 2010. Yesterday's heroes: Compensation and creative risk-taking. NBER working paper No. 16176.

Chernykh, L., Cole, R.A., 2011. Does deposit insurance improve financial intermediation? Evidence from the Russian experiment. Journal of Banking and Finance 35 (2), 388402.

Claessens, S., Klingebiel, D., 2000. Competition and scope of activities in financial services. Mimeo. World Bank, Washington, DC. April.

Curry, T.J., Elmer, P.J., Fissel, G.S., 2001. Regulator Use of Market Data to Improve the Identification of Bank Financial Distress. Working Paper No. 2001-01. Federal Deposit Insurance Corporation.

Curry, T.J., Elmer, P.J., Fissel, G.S., Hanweck, G., 2003. Market Information, Bank Holding Company Risk, and Market Discipline. Working Paper No. 2003-04. Federal Deposit Insurance Corporation.

Demirgüç-Kunt, A., Detragiache, E., 2002. Does deposit insurance increase banking system stability? An empirical investigation. Journal of Monetary Economics 49 (7), 13731406. 
Demirgüç-Kunt, A., Huizinga, H., 2004. Market discipline and deposit insurance. Journal of Monetary Economics 51 (2), 375-399.

Demirgüç-Kunt, A., Kane, E., 2002. Deposit insurance around the globe: Where does it work? Journal of Economic Perspectives 16 (2), 175-195.

Demirgüç-Kunt, A., Detragiache, E., Merrouche, O., 2010. Bank capital: Lessons from the financial crisis. Working paper WP/10/286, International Monetary Fund.

Demirgüç-Kunt, A., Huizinga, H., 2010. Bank activity and funding strategies: The impact on risk and return. Journal of Financial Economics 98, 626-650.

Demirgüç-Kunt, A., Kane, E.J., Laeven, L. 2008. Determinants of deposit-insurance adoption and design. Journal of Financial Intermediation, 17, 407-438.

Dewatripont, M., Tirole, J., 1994. The Prudential Regulation of Banks. MIT Press, Cambridge.

Djankov, S., La Porta, R., Lopez-de-Silanes, F., Shleifer, A., 2008. The law and economics of self- dealing. Journal of Financial Economics 88, 430-465.

Djankov, S., La Porta, R., Lopez-de-Silanes, F., Shleifer, A., 2002.The regulation of entry. The Quarterly Journal of Economics 117, 1-37.

Elmer, P.J., Fissel, G.S., 2001. Forecasting Bank Failure from Momentum Patterns in Stock Returns. Unpublished Paper. FDIC.

Fahlenbrach, R., Prilmeier, R., Stultz, R.M., 2012. This time is the same: Using bank performance in 1998 to explain bank performance during the recent financial crisis. Journal of Finance 67, 2139-2185.

Fernández, A.I., González, F., 2005. How accounting and auditing systems can counteract risk-shifting of safety-nets in banking: Some international evidence. Journal of Financial Stability 1, 466-500.

Gorton, G., 2010. Slapped by the Invisible Hand. Oxford University Press, Oxford.

Gorton, G., Winton, A., 2003. Financial intermediation. In: Constantinides, G., Harris, M., Stulz, R. (Eds.), Handbook of the Economics of Finance. North-Holland, Amsterdam.

Greenspan, A., 1998. The Role of Capital in Optimal Banking Supervision and Regulation. In Proceedings of a Conference on Financial Services at the Crossroads: Capital Regulation in the Twenty-First Century. Federal Reserve Bank of New York Economic Policy Review 4, n.3:161-68.

Gropp, R., Vesala, J., 2004. Deposit Insurance, Moral Hazard and Market Monitoring. European Central Bank Working Paper No. 302. 
Gunther, J.W., Levonian, M.E., Moore, R.R., 2001. Can the stock market tell bank supervisors anything they don't already know? Federal Reserve Bank of Dallas Economic and Financial Review 2, 2-9.

Hall, J.R., King, T.B., Meyer, A.P., Vaughn, M.D., 2001. What Can Bank Supervisors Learn from Equity Markets? A Comparison of the Factors Affecting Market-Based Risk Measures and BOPEC Scores. Working Paper No. 2002-06. Federal Reserve Bank of St. Louis.

Haq, M., Heaney, R., 2012. Factors determining European bank risk. Journal of International Financial Markets, Institutions \& Money 22, 696-718.

Hoque, H., 2013, From the credit crisis to the sovereign debt crisis: Determinants of share price performance of global banks. International Review of Financial Analysis 30, $334-350$.

Hovakimian, A., Kane, E.J., Laeven, L., 2003. How country and safety net characteristics affect bank risk-shifting? Journal of Financial Services Research 23, 177-204.

Hui, C.-H., Chung, T.-K. 2011, Crash risk of the euro in the sovereign debt crisis of 20092010, Journal of Banking and Finance 35, 2945-2955.

Ioannidou, V.P., Penas, M.F., 2010. Deposit insurance and bank risk-taking: Evidence from internal loan ratings. Journal of Financial Intermediation 19 (1), 95-115.

Ivashina, V., Scharfstein, D., 2010.Bank lending during the financial crisis of 2008. Journal of Financial Economics 97, 319-338.

John, K., John, T.A., Saunders, A., 1994. Universal banking and firm risk taking. Journal of Banking and Finance 18, 307-323.

John, K., Litov, L., Yeung, B., 2008. Corporate governance and risk taking. Journal of Finance 63, 1679-1728.

Kane, E., 1990. Principal-agent problems in S\&L salvage. Journal of Finance 45, 755-764.

Karels, G.V., McClatchey, C.A., 1999. Deposit insurance and risk-taking behavior in the credit union industry. Journal of Banking and Finance 23 (1), 105-134.

Kaufmann, D., Kraay, A., Mastruzzi, M., 2008. Governance matters VII: Aggregate and individual governance indicators, 1996-2007. Unpublished working paper, World Bank.

Keeley, M.C., Furlong, F.T., 1990. A re-examination of mean-variance analysis of bank capital regulations. Journal of Banking and Finance 14, 69-84.

Kim, D., Santomero, A.M., 1988. Risk in banking and capital regulation. Journal of Finance $35,1219-1233$. 
Klomp, J., de Haan, J., 2012. Banking risk and regulation: Does one size fit all? Journal of Banking and Finance 36, 3197-3212.

Koehn, M., Santomero, A.M., 1980.Regulation of bank capital and portfolio risk. Journal of Finance 35, 1235-1250.

Krainer, J., Lopez, J.A., 2001. Incorporating Equity Market Information into Supervisory Monitoring Models. Working Paper 2001-14.Federal Reserve Bank of San Francisco.

Krainer, J., Lopez, J.A., 2003. How might financial market information be used for supervisory purposes? Federal Reserve Bank of San Francisco Economic Review, 2945.

Krishnan, C.N.V., Ritchken, P.H., Thomson, J.B., 2005. Monitoring and controlling bank risk: Does risky debt help? Journal of Finance 60, 343-378.

La Porta, R., Lopez-de-Silanes, F., Shleifer, A., Vishny, R., 1998. Law and finance. Journal of Political Economy 106, 1113-1155.

Laeven, L., Levine, R., 2007. Is there a diversification discount in financial conglomerates? Journal of Financial Economics 85, 331-367.

Laeven, L., Levine, R., 2008. Bank governance, regulation, and risk taking. Journal of Financial Economics 93, 259-275.

Laeven, L., 2002. Pricing Deposit Insurance. World Bank Policy Research Working Paper No. 2781.

Lane, P.R., Milesi-Ferretti, G.M., 2012.External adjustment and the global crisis. Journal of International Economics 88, 252-265.

Lane, P.R.,2012. The European sovereign debt crisis. Journal of Economic Perspectives 26, 49-68.

López-Espinosa, G., Moreno, A., Rubia, A., Valderrama, L., 2012. Short-term wholesale funding and systemic risk: A global CoVaR approach. Journal of Banking and Finance 36, 3150-3162.

McGuire, P., von Peter, G., 2009. The US dollar shortage in global banking. BIS Quarterly Review, March 2009, 47-63.

Merton, R.C., 1977. On the pricing of contingent claims and the Modigliani-Miller theorem. Journal of Financial Economics 15 (2), 241-250.

National Commission on the Causes of the Financial and Economic Crisis in United States. 2011. The Financial Crisis Inquiry Report: Final Report of the National Commission on the Causes of the Financial and Economic Crisis in United States. U.S. Government Printing Office, Washington, D.C. 
Pasiouras, F., Gaganis, C., Zopoundis, C., 2006. The impact of bank regulations, supervision, market structure, and bank characteristics on individual bank ratings: a cross-country analysis. Review of Quantitative Finance and Accounting 27, 403-438.

Quintyn, M., Taylor, M., 2002.Regulatory and supervisory independence and financial stability. International Monetary Fund working paper No. 02/46, March.

Santos, J.A.C., 2001. Bank capital regulation in contemporary banking theory: A review of the literature. Financial Markets, Institutions and Instruments 10 (2), 41-84.

Saunders, A., 1985. Conflicts of interest: An economic view. In: Walter, I. (Ed.), Deregulating Wall Street: Commercial Bank Penetration of the Corporate Securities Market. Wiley, New York, pp. 207-230.

Shleifer, A., Vishny, R., 1998. The Grabbing Hand: Government Pathologies and their Cures. Harvard Univ. Press, Cambridge, MA.

Stiglitz, J.E., 2010. Freefall: America, Free Markets, and the Sinking of the World Economy. Norton, New York. 
Figure 1: Market Capitalization to GDP

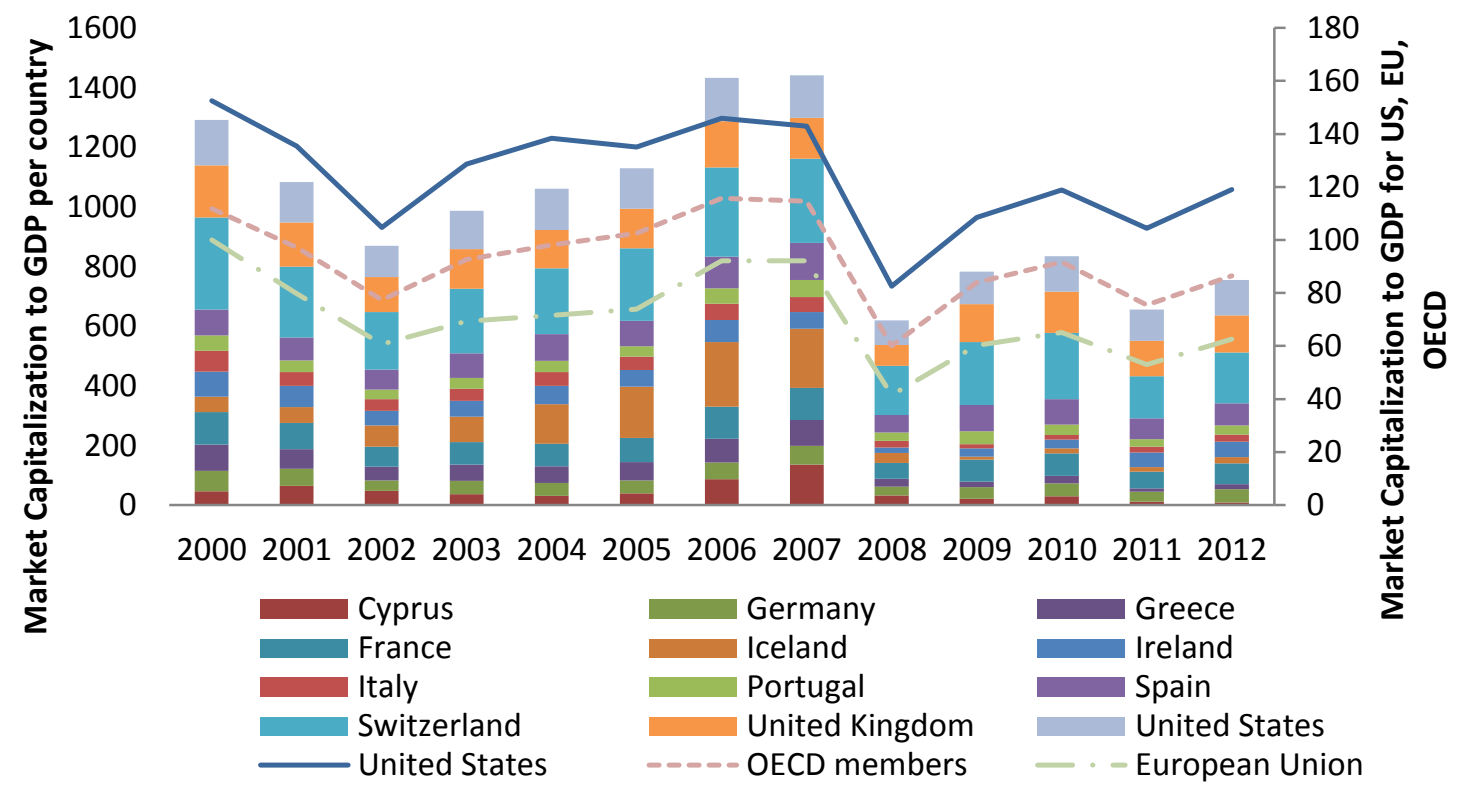

Source: World Bank

Figure 2: Total Bank Loans Outstanding

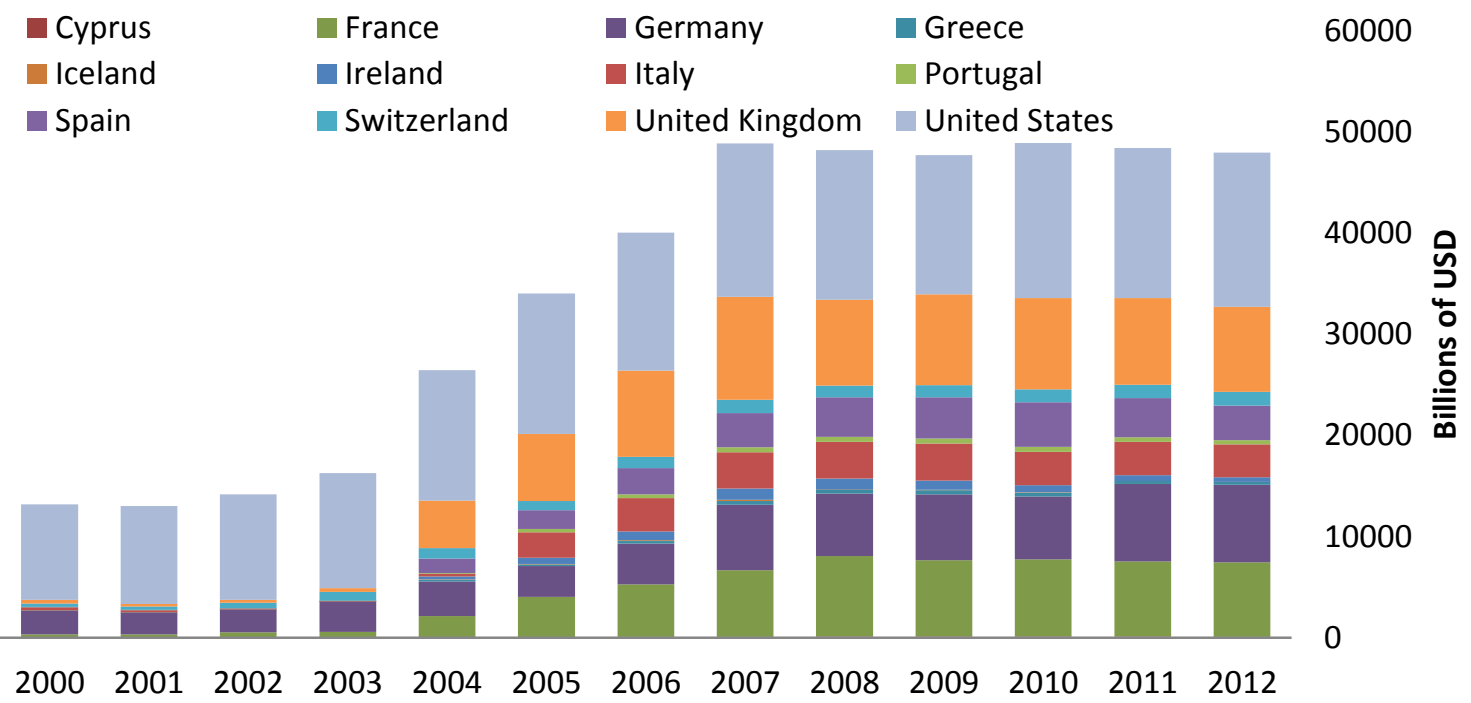

Source: Bankscope 
Figure 3: Logarithmic Changes in Total Loans Outstanding

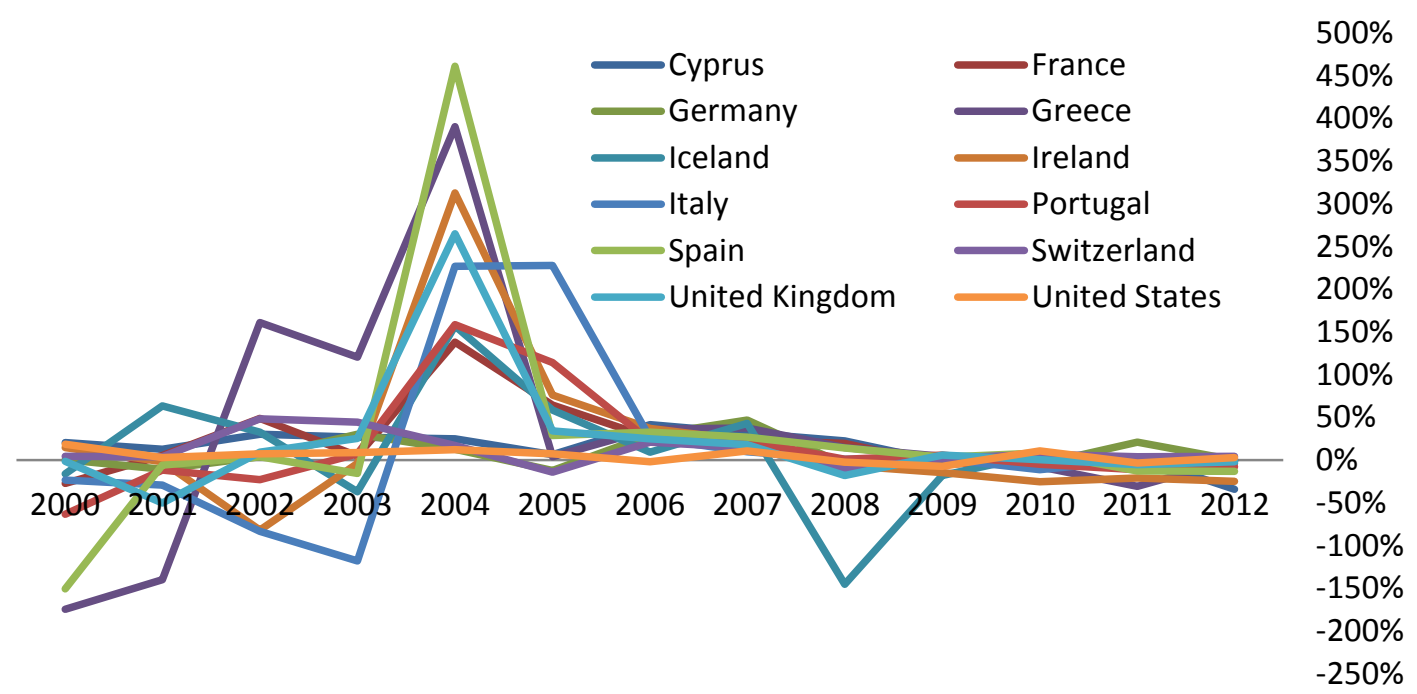

Source: Bankscope

\section{Figure 4: Public Debt to GDP}

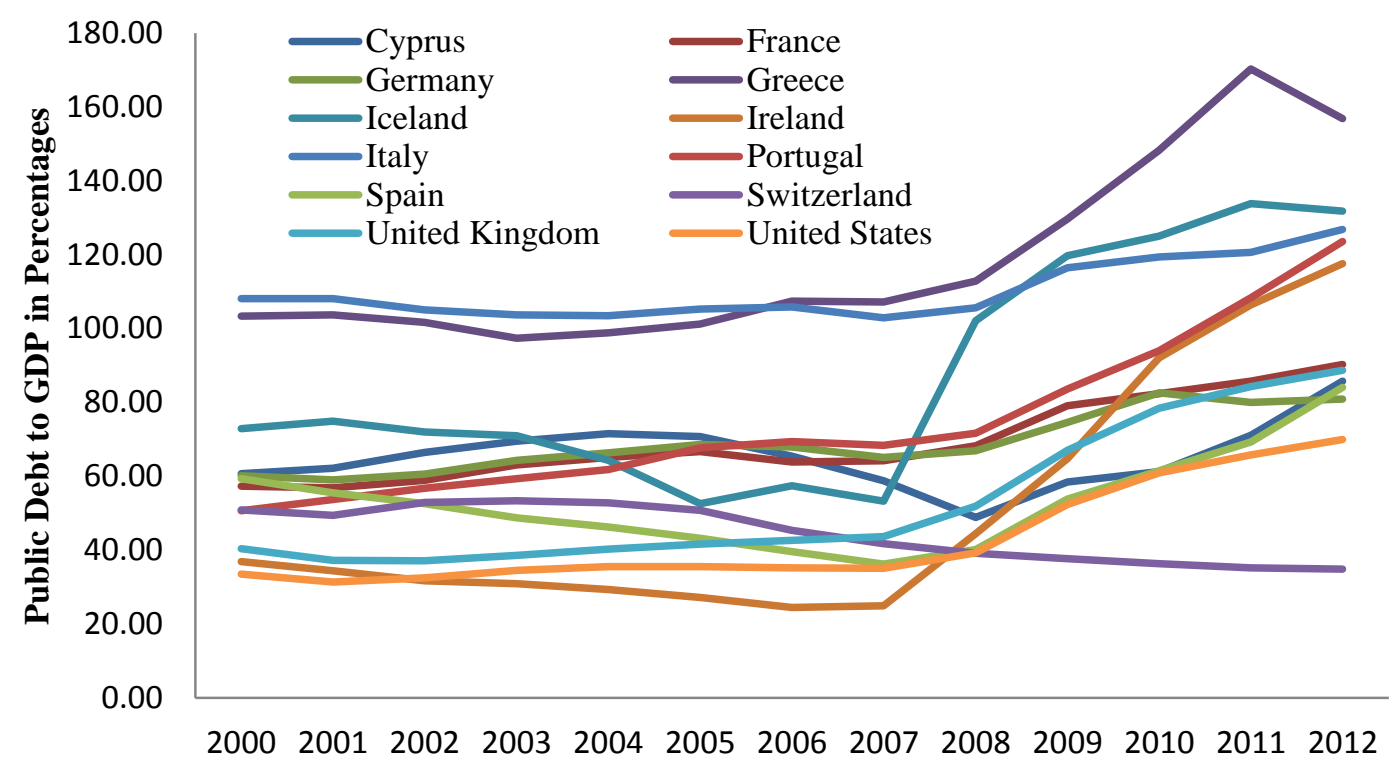

Source: IMF Public Database, Eurostat, World Bank, OECD. 
Table 1.Descriptive statistics.

\begin{tabular}{|c|c|c|c|c|c|}
\hline & $\mathbf{N}$ & Mean & Median & p5 & p95 \\
\hline \multicolumn{6}{|c|}{ The $2007-08$ credit crisis } \\
\hline $\log z$ & 311 & 3.106 & $2.965^{* * *}$ & 1.836 & 4.315 \\
\hline MES & 378 & $-0.075^{* * *}$ & $-0.074^{* * *}$ & -0.099 & -0.050 \\
\hline Beta & 326 & $1.006^{*}$ & 1.012 & 0.317 & 1.693 \\
\hline Idiosyncratic & 378 & $42.335^{* * *}$ & $37.669^{* * *}$ & 19.108 & 79.695 \\
\hline BHAR & 346 & -0.502 & -0.571 & -0.894 & 0.022 \\
\hline Tier I capital & 295 & $9.739^{* * *}$ & $8.850^{* * *}$ & 5.840 & 16.530 \\
\hline Liquidity & 342 & $17.268^{* * * *}$ & $14.030^{* *}$ & 2.910 & 42.180 \\
\hline Deposit & 342 & 61.254 & 67.476 & 16.565 & 90.393 \\
\hline Funding fragility & 342 & $21.259^{* *}$ & $11.826^{* *}$ & 0.952 & 73.279 \\
\hline Loan & 342 & $59.094^{*}$ & $59.826^{* * *}$ & 32.501 & 82.764 \\
\hline Income diversity & 342 & $0.177^{*}$ & $0.120^{*}$ & -0.038 & 0.737 \\
\hline GDP & 378 & 24.196 & 29.380 & 0.910 & 46.520 \\
\hline \multirow[t]{2}{*}{ Current acc. bal. } & 378 & 1.806 & 1.532 & -10.013 & 12.335 \\
\hline & \multicolumn{5}{|c|}{ The sovereign debt crisis of 2011} \\
\hline $\log z$ & 311 & 2.765 & 2.730 & 2.124 & 3.483 \\
\hline MES & 378 & -0.066 & -0.060 & -0.095 & -0.050 \\
\hline Idiosyncratic & 372 & 48.606 & 44.200 & 14.161 & 86.492 \\
\hline Beta & 310 & 1.072 & 1.028 & 0.358 & 1.852 \\
\hline BHAR & 369 & -0.283 & -0.253 & -0.711 & 0.068 \\
\hline ROA & 354 & 0.716 & 0.605 & -0.158 & 2.309 \\
\hline Tier I capital & 321 & 11.159 & 10.400 & 6.800 & 17.100 \\
\hline Liquidity & 356 & 14.668 & 11.400 & 3.180 & 34.980 \\
\hline Deposit & 356 & 62.306 & 66.421 & 19.819 & 91.981 \\
\hline Funding fragility & 356 & 17.710 & 10.310 & 0.484 & 67.742 \\
\hline Loan & 356 & 61.178 & 62.528 & 34.360 & 82.639 \\
\hline Income diversity & 354 & 0.144 & 0.100 & -0.021 & 0.490 \\
\hline GDP & 378 & 24.56 & 30.22 & 1.38 & 46.83 \\
\hline Current acc. bal. & 378 & 1.060 & 1.23 & -6.50 & 12.32 \\
\hline \multirow[t]{2}{*}{ Total assets (bn\$) } & 352 & 204.00 & 45.20 & 13.33 & 1176.21 \\
\hline & \multicolumn{5}{|c|}{ Country-level variables } \\
\hline Concentration & 378 & 0.52 & 0.50 & 0.32 & 0.85 \\
\hline ADRI & 378 & 3.69 & 4.00 & 1.00 & 5.00 \\
\hline Institute & 378 & 0.83 & 1.18 & -0.56 & 1.68 \\
\hline Official & 378 & 10.11 & 10.00 & 7.00 & 13.00 \\
\hline Capital & 378 & 5.91 & 6.00 & 4.00 & 8.00 \\
\hline Restrict & 378 & 9.52 & 10.00 & 5.00 & 13.00 \\
\hline Private & 378 & 6.74 & 7.00 & 5.00 & 8.00 \\
\hline Deposit insurance & 378 & 0.84 & 1.00 & 0.00 & 1.00 \\
\hline
\end{tabular}

The sample includes the largest 378 banks by asset size at the end of 2006 for which we could find accounting and share price data. All the variables are defined in Appendix I. ***,**, and * represent whether the means (medians) are significantly different between 2007-08 and 2011 at 1\%, 5\%, and $10 \%$ levels, respectively. 
Table 2.Cross-country variation in selected variables.

\begin{tabular}{|c|c|c|c|c|c|c|c|c|c|c|c|}
\hline Country & $\mathbf{N}$ & $\begin{array}{c}\log Z \\
2007\end{array}$ & $\begin{array}{c}\log Z \\
2011\end{array}$ & MES 2007 & MES 2011 & $\begin{array}{c}\text { Idiosync } \\
2007 \\
\end{array}$ & $\begin{array}{c}\text { Idiosync } \\
2011 \\
\end{array}$ & $\begin{array}{c}\text { BETA } \\
2007\end{array}$ & Beta 2011 & $\begin{array}{l}\text { BHAR } \\
\text { crisis07 }\end{array}$ & $\begin{array}{l}\text { BHAR } \\
\text { crisis11 }\end{array}$ \\
\hline AUSTRALIA & 6 & 1.140 & 1.048 & -0.078 & -0.060 & 0.271 & 0.407 & 1.12 & 1.15 & -0.637 & -0.253 \\
\hline AUSTRIA & 5 & 1.103 & 0.929 & -0.062 & -0.058 & 0.184 & 0.273 & 0.67 & 0.62 & -0.332 & -0.288 \\
\hline CANADA & 9 & 1.120 & 0.992 & -0.076 & -0.0568 & 0.267 & 0.407 & 0.63 & 1.10 & -0.556 & -0.167 \\
\hline CHILE & 5 & & 1.109 & -0.112 & -0.203 & 0.454 & 0.823 & 0.87 & 0.98 & -0.471 & -0.36 \\
\hline CHINA-PEOPLE'S REP. & 18 & 0.704 & 1.013 & -0.068 & -0.058 & 0.434 & 0.415 & 1.01 & 0.95 & -0.529 & -0.22 \\
\hline FRANCE & 17 & 1.161 & 0.905 & -0.071 & -0.065 & 0.302 & 0.431 & 1.08 & 1.00 & -0.683 & -0.428 \\
\hline GERMANY & 8 & 1.048 & 0.942 & -0.074 & -0.075 & 0.357 & 0.519 & 1.34 & 1.16 & -0.692 & -0.348 \\
\hline GREECE & 6 & 1.188 & 1.018 & -0.075 & -0.103 & 0.436 & 0.734 & 1.43 & 1.32 & -0.759 & -0.902 \\
\hline HONG KONG & 6 & 1.193 & 1.132 & -0.078 & -0.061 & 0.326 & 0.298 & 1.19 & 0.89 & -0.570 & -0.258 \\
\hline INDIA & 28 & 1.007 & 1.014 & -0.071 & -0.061 & 0.574 & 0.491 & 1.07 & 1.04 & -0.483 & -0.500 \\
\hline INDONESIA & 6 & 1.198 & 1.176 & -0.092 & -0.072 & 1.087 & 0.674 & 1.09 & 1.24 & -0.654 & -0.212 \\
\hline ISRAEL & 5 & 1.053 & 1.047 & -0.066 & -0.068 & 0.340 & 0.451 & 1.12 & 1.12 & -0.578 & -0.403 \\
\hline ITALY & 21 & 0.937 & 1.031 & -0.069 & -0.068 & 0.302 & 0.478 & 0.93 & 0.91 & -0.552 & -0.485 \\
\hline JAPAN & 71 & 1.025 & 0.898 & -0.070 & -0.053 & 0.392 & 0.379 & 0.67 & 0.86 & -0.230 & 0.003 \\
\hline POLAND & 9 & 1.479 & 0.999 & -0.083 & -0.078 & 0.420 & 0.579 & 1.38 & 0.94 & -0.711 & -0.511 \\
\hline RUSSIAN FEDERATION & 6 & 1.112 & 1.256 & -0.071 & -0.081 & 0.626 & 0.574 & 0.74 & 0.55 & -0.738 & -0.296 \\
\hline SAUDI ARABIA & 6 & 1.393 & 1.034 & -0.076 & -0.057 & 0.363 & 0.464 & - & 0.84 & -0.342 & -0.12 \\
\hline SPAIN & 13 & 1.126 & 1.018 & -0.064 & -0.073 & 0.378 & 0.554 & 0.99 & 0.93 & -0.577 & -0.453 \\
\hline SWITZERLAND & 5 & 1.296 & 0.986 & -0.078 & -0.070 & 0.380 & 0.649 & 1.48 & 1.67 & -0.604 & -0.438 \\
\hline TAIWAN & 5 & 1.035 & 1.015 & -0.061 & -0.060 & 0.518 & 0.530 & 1.01 & 1.05 & -0.313 & -0.281 \\
\hline THAILAND & 7 & 0.935 & 1.076 & -0.115 & -0.081 & 0.614 & 0.633 & 0.99 & 1.33 & -0.613 & -0.257 \\
\hline TURKEY & 8 & 1.246 & 1.209 & -0.079 & -0.073 & 0.770 & 0.568 & 1.16 & 1.18 & -0.634 & -0.454 \\
\hline UNITED ARAB EMIRATES & 6 & 1.208 & 1.003 & -0.070 & -0.054 & 0.476 & 0.416 & - & 1.30 & -0.406 & -0.071 \\
\hline UNITED KINGDOM & 16 & 0.779 & 0.858 & -0.081 & -0.0585 & 0.343 & 0.473 & 1.28 & 1.54 & -0.664 & -0.224 \\
\hline USA & 18 & 1.197 & 0.917 & -0.085 & -0.071 & 0.381 & 0.727 & 1.45 & 1.78 & -0.690 & -0.300 \\
\hline
\end{tabular}

The sample includes the largest 378 banks by asset size at the end of 2006 for which we could find accounting and share price data. In this table we present the results for countries that have at least 5 banks. BHAR 2007-08 is the buy-and-hold return for the sample banks during the June 2007 to December 2008 period. BHAR 11 is the buy-and-hold return from June 2011 until December 2011. Beta2007 is estimated on a regression of weekly stock returns of individual stocks in excess of 3-month T-bills against the MSCI World Index from June 2007 to December 2008. Idiosync2007 is the idiosyncratic volatility, which is the annualized standard deviation from the market model regression residuals that estimate

beta2007. Beta2011 is estimated on a regression of the weekly stock returns of individual stocks in excess of 3-month T-bills against the MSCI World Index from June 2011 until December 2011. Idiosync2010 is the idiosyncratic volatility, which is the annualized standard deviation from the market model regression residuals that estimate beta2011. 
Table 3.Risk analysis, the credit crisis.

\begin{tabular}{|c|c|c|c|c|c|c|c|c|c|c|c|c|c|c|c|c|}
\hline & \multicolumn{4}{|c|}{$\log z$} & \multicolumn{4}{|c|}{ MES } & \multicolumn{4}{|c|}{ Idiosyncratic risk } & \multicolumn{4}{|c|}{ Beta } \\
\hline & \multicolumn{2}{|c|}{ (1) } & \multicolumn{2}{|c|}{$(2)$} & \multicolumn{2}{|c|}{ (3) } & \multicolumn{2}{|c|}{ (4) } & \multicolumn{2}{|c|}{ (5) } & \multicolumn{2}{|c|}{ (6) } & \multicolumn{2}{|c|}{ (7) } & \multicolumn{2}{|c|}{$(8)$} \\
\hline & Coef. & $t$-stat & Coef. & $t$-stat & Coef. & $t$-stat & Coef. & $t$-stat & Coef. & $t$-stat & Coef. & $t$-stat & Coef. & $t$-stat & Coef. & $t$-stat \\
\hline Cons & $4.532^{* * * *}$ & (12.45) & $2.683^{* * *}$ & $(4.34)$ & $-10.348^{* * *}$ & $(-11.51)$ & $-12.103^{* * *}$ & $(-5.44)$ & $52.856^{* * * *}$ & $(5.83)$ & 25.640 & $(1.28)$ & $1.438^{* * * *}$ & $(5.72)$ & 0.041 & $(0.07)$ \\
\hline Official & 0.022 & $(0.85)$ & 0.012 & $(0.64)$ & -0.059 & $(-0.99)$ & -0.099 & $(-1.41)$ & $1.728^{* * * *}$ & $(2.88)$ & $1.454^{* *}$ & $(2.32)$ & $0.045^{* * * *}$ & $(2.77)$ & $0.066^{* * * *}$ & $(3.50)$ \\
\hline Capital & -0.043 & $(-1.24)$ & 0.013 & $(0.47)$ & 0.062 & $(0.81)$ & 0.058 & $(0.59)$ & $-1.308^{* *}$ & $(-2.65)$ & $-0.734^{*}$ & $(-1.83)$ & $-0.055^{* *}$ & $(-2.47)$ & $-0.028^{* *}$ & $(-2.03)$ \\
\hline Restriction & $-0.043^{*}$ & $(-2.08)$ & $-0.034^{*}$ & $(-1.74)$ & $0.221^{* * * *}$ & $(4.66)$ & $0.269^{* * *}$ & $(3.94)$ & $-0.833^{*}$ & $(-1.74)$ & -0.937 & $(-1.49)$ & -0.018 & $(-1.39)$ & 0.000 & $(-0.01)$ \\
\hline Private monitoring & $-0.151^{* * * *}$ & $(-3.07)$ & $-0.115^{* *}$ & $(2.32)$ & 0.174 & $(1.50)$ & $0.294^{*}$ & $(1.78)$ & -1.275 & $(-1.10)$ & -1.550 & $(-1.07)$ & $-0.057^{*}$ & $(-1.79)$ & $-0.097^{* *}$ & $(-2.26)$ \\
\hline Deposit insurance & $-0.047^{* * *}$ & $(-2.36)$ & $-0.041^{* *}$ & $(2.35)$ & $-0.674^{* *}$ & $(-2.18)$ & $-0.690^{*}$ & $(-1.69)$ & $2.119^{* * *}$ & $(2.66)$ & $2.626^{* * *}$ & $(2.70)$ & 0.069 & $(0.77)$ & 0.013 & $(0.12)$ \\
\hline BHAR & & & 0.001 & $(0.59)$ & & & -0.003 & $(-0.62)$ & & & $0.093^{* *}$ & $(2.27)$ & & & $0.004^{* * * *}$ & $(2.87)$ \\
\hline Tier 1 & & & $0.101^{* * *}$ & $(8.90)$ & & & 0.057 & $(1.43)$ & & & 0.412 & $(1.12)$ & & & -0.001 & $(-0.08)$ \\
\hline Funding fragility & & & -0.001 & $(-0.58)$ & & & 0.006 & $(0.63)$ & & & $-0.284^{* * * *}$ & $(-3.65)$ & & & -0.002 & $(-0.70)$ \\
\hline Loans & & & 0.002 & $(0.55)$ & & & -0.001 & $(-0.10)$ & & & 0.017 & $(0.17)$ & & & -0.002 & $(-0.67)$ \\
\hline Income diversity & & & -0.033 & $(-0.30)$ & & & 0.121 & $(0.31)$ & & & 0.990 & $(0.27)$ & & & -0.081 & $(-0.79)$ \\
\hline Size & & & $-0.158^{* *}$ & $(-2.11)$ & & & -0.124 & $(-0.47)$ & & & $6.083^{* * *}$ & $(2.51)$ & & & $0.257^{* * *}$ & (3.59) \\
\hline GDP per cap & & & 0.001 & $(0.22)$ & & & 0.003 & $(0.26)$ & & & -0.144 & $(-1.60)$ & & & $0.005^{*}$ & $(1.73)$ \\
\hline Current acc. bal. & & & -0.006 & $(-1.23)$ & & & -0.003 & $(-0.19)$ & & & -0.201 & $(-1.27)$ & & & $-0.015^{* * *}$ & $(-2.92)$ \\
\hline Concentration & & & $0.532^{* *}$ & $(2.28)$ & & & 0.794 & $(0.94)$ & & & 5.247 & $(0.70)$ & & & 0.113 & $(0.49)$ \\
\hline ADRI & & & -0.067 & $(-1.60)$ & & & 0.128 & $(0.87)$ & & & 0.056 & $(0.04)$ & & & -0.021 & $(-0.49)$ \\
\hline Adj. $R^{2}(\%)$ & & 5.07 & & 35.86 & & 8.04 & & 6.72 & & 1.60 & & 9.28 & & 2.40 & & 17.54 \\
\hline $\mathrm{N}$ & & 312 & & 289 & & 350 & & 275 & & 378 & & 295 & & 341 & & 266 \\
\hline
\end{tabular}

All the variables are defined in Appendix I. All the accounting data are taken end of 2006. t-statistics are reported in parentheses. The standard errors for the regressions are estimated with country-level clustering. $* * *, * *$, and $*$ represent significance at $1 \%, 5 \%$, and $10 \%$, respectively. 
Table 4.Stock market performance, the credit crisis.

\begin{tabular}{|c|c|c|c|c|c|c|c|c|}
\hline & \multicolumn{8}{|c|}{ Dependent Variable: BHAR 2007-08 } \\
\hline & $(1)$ & & $(2)$ & & $(3)$ & & $(4)$ & \\
\hline & Coef. & $t$-stat & Coef. & $t$-stat & Coef. & $t$-stat & Coef. & $t$-stat \\
\hline Constant & $-118.438^{* * *}$ & $(-7.37)$ & $-68.023^{* * *}$ & $(-5.57)$ & $-63.911^{* * * *}$ & $(-4.26)$ & $-46.089^{* * *}$ & $(-2.88)$ \\
\hline Official & $1.824^{* *}$ & $(1.99)$ & $2.888^{* * *}$ & $(4.90)$ & $2.915^{* * *}$ & $(4.57)$ & $2.641^{* * *}$ & $(4.08)$ \\
\hline Capital & 1.33 & $(1.10)$ & 0.983 & $(1.21)$ & 0.05 & $(0.05)$ & 0.665 & $(0.71)$ \\
\hline Restriction & $2.009^{* * * *}$ & $(2.62)$ & $1.135^{* *}$ & $(2.27)$ & $0.891^{* * *}$ & $(2.32)$ & $0.892^{*}$ & $(2.27)$ \\
\hline Private monitoring & $3.188^{*}$ & $(1.69)$ & $1.642^{* * *}$ & $(2.25)$ & $2.806^{*}$ & $(1.91)$ & $1.573^{*}$ & $(2.10)$ \\
\hline Deposit insurance & -5.436 & $(-1.18)$ & 3.749 & $(1.04)$ & $7.796^{*}$ & $(1.72)$ & 3.977 & $(0.84)$ \\
\hline Tier1 & 0.649 & $(1.33)$ & $0.616^{*}$ & $(1.70)$ & $0.731^{* *}$ & $(1.92)$ & 0.257 & $(0.66)$ \\
\hline $\log z$ & & & -0.694 & $(-0.86)$ & -0.68 & $(-0.85)$ & -0.939 & $(-1.16)$ \\
\hline Idiosyncratic volatility & & & $-0.133^{*}$ & $(-1.86)$ & $-0.267^{* * *}$ & $(-3.14)$ & $-0.206^{* *}$ & $(-2.48)$ \\
\hline Beta & & & $-43.362^{* * *}$ & $(-15.78)$ & $-39.225^{* * * *}$ & $(-12.02)$ & $-41.394^{* * *}$ & $(-12.55)$ \\
\hline Funding fragility & & & & & 0.109 & $(1.38)$ & & \\
\hline Deposit & & & & & & & 0.112 & $(1.70)$ \\
\hline Liquid & & & & & -0.07 & $(-0.65)$ & & \\
\hline Loan & & & & & & & $-0.279^{* * *}$ & $(-3.16)$ \\
\hline GDP per cap & & & & & $-0.286^{* * *}$ & $(-2.65)$ & & \\
\hline Current acc. bal. & & & & & $0.422^{* * *}$ & $(2.31)$ & 0.099 & $(0.52)$ \\
\hline Concentration & & & & & -9.595 & $(-1.20)$ & -5.685 & $(-0.65)$ \\
\hline ADRI & & & & & 0.756 & $(0.50)$ & 0.775 & $(0.52)$ \\
\hline Institution & & & & & & & -0.923 & $(-0.34)$ \\
\hline Adj. $R^{2}(\%)$ & & 8.13 & & 61.98 & & 63.14 & & 63.71 \\
\hline $\mathrm{N}$ & & 275 & & 247 & & 247 & & 247 \\
\hline
\end{tabular}

The dependent variable is BHAR 2007-08 for the sample banks. BHAR 2007-08 is calculated for the sample banks during the June 2007 to December 2008 period. All the variables are defined in Appendix I. All the accounting variables are pooled at the end of 2006. t-statistics are reported in parentheses. The standard errors for the regressions are estimated with country-level clustering. $* * *, * *, *$ represent significance at $1 \%, 5 \%$, and $10 \%$, respectively. 
Table 5.Risk analysis, the sovereign debt crisis.

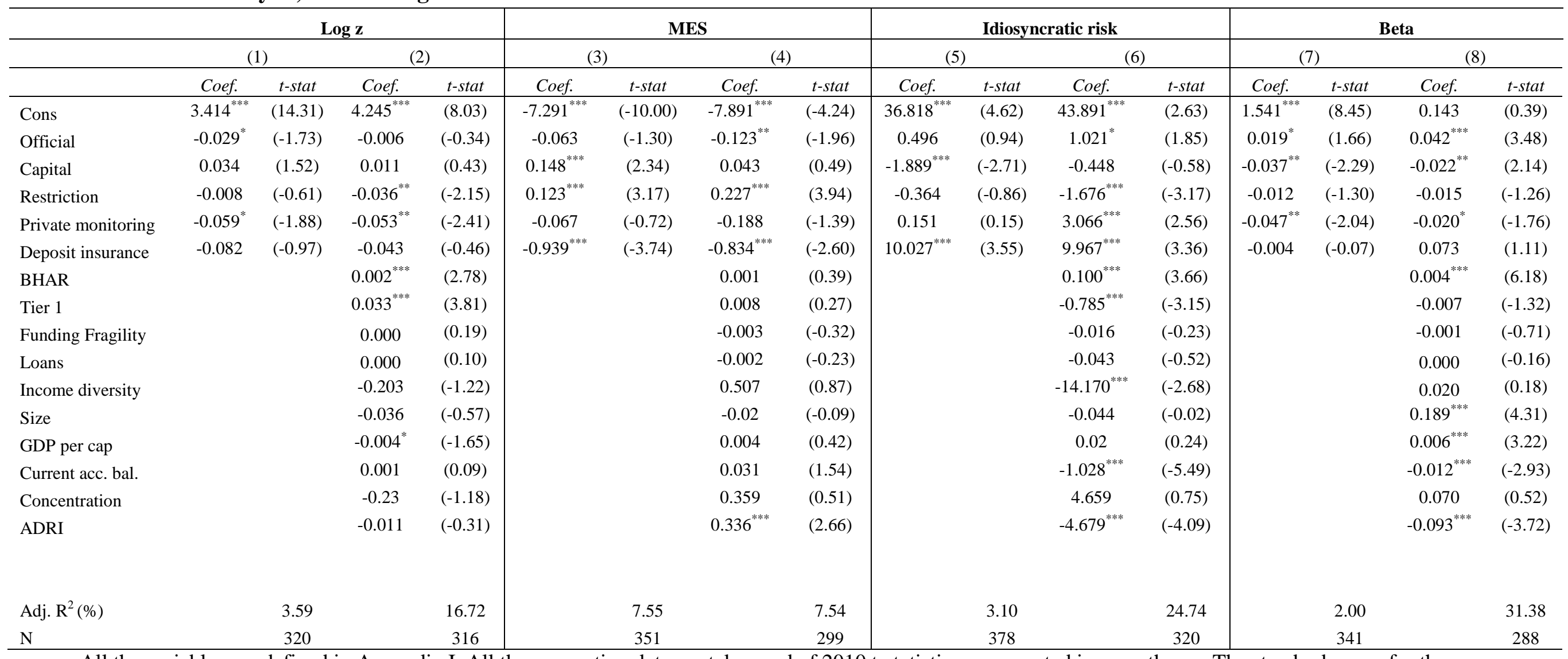

All the variables are defined in Appendix I. All the accounting data are taken end of $2010 \mathrm{t}$-statistics are reported in parentheses. The standard errors for the regressions are estimated with country level clustering. $* * * * *$, and * represent significance at $1 \%, 5 \%$, and $10 \%$, respectively. 
Table 6. Stock market performance, the sovereign debt crisis

\begin{tabular}{|c|c|c|c|c|c|c|c|c|}
\hline & \multicolumn{8}{|c|}{ Dependent Variable: BHAR 2010-11 } \\
\hline & $(1)$ & & $(2)$ & & $(3)$ & & (4) & \\
\hline & Coef. & $t$-stat & Coef. & $t$-stat & Coef. & $t$-stat & Coef. & $t$-stat \\
\hline Constant & $-85.803^{* * *}$ & $(-6.59)$ & $-50.931^{* * * *}$ & $(-2.83)$ & -30.512 & $(-1.62)$ & $-61.175^{* * * *}$ & $(-3.19)$ \\
\hline Official & $2.419^{* * *}$ & $(3.08)$ & $2.780^{* * *}$ & $(3.80)$ & $1.523^{* *}$ & $(2.21)$ & $0.403^{* * *}$ & $(2.59)$ \\
\hline Capital & 0.603 & $(0.58)$ & -0.091 & $(-0.10)$ & -1.384 & $(-1.40)$ & 0.397 & $(0.40)$ \\
\hline Restriction & -0.155 & $(-0.24)$ & -0.398 & $(-0.66)$ & -0.113 & $(-0.16)$ & 0.032 & $(0.05)$ \\
\hline Private monitoring & $5.018^{* * *}$ & $(3.49)$ & $5.187^{* * *}$ & $(3.44)$ & $2.852^{* *}$ & $(1.86)$ & $2.567^{*}$ & $(1.79)$ \\
\hline Deposit insurance & $-12.010^{* * *}$ & $(-3.11)$ & $-2.976^{* * *}$ & $(-2.72)$ & $-3.608^{* * * *}$ & $(-2.83)$ & $-4.332^{* * *}$ & $(-2.95)$ \\
\hline Tier1 & $0.651^{*}$ & $(1.85)$ & 0.012 & $(0.03)$ & 0.078 & $(0.23)$ & $0.610^{*}$ & $(1.78)$ \\
\hline $\log z$ & & & -3.242 & $(-1.26)$ & -3.249 & $(-1.38)$ & -0.515 & $(-0.22)$ \\
\hline Idiosyncratic volatility & & & $-0.627^{* * * *}$ & $(-6.82)$ & $-0.498^{* * *}$ & $(-5.85)$ & $-0.458^{* * *}$ & $(-5.65)$ \\
\hline Beta & & & -0.966 & $(-0.27)$ & -1.6 & $(-0.49)$ & 0.407 & $(0.13)$ \\
\hline Funding fragility & & & & & $-0.296^{* * *}$ & $(-3.33)$ & & \\
\hline Deposit & & & & & & & $0.369^{* * *}$ & $(5.60)$ \\
\hline Liquid & & & & & 0.012 & $(0.09)$ & & \\
\hline Loan & & & & & & & 0.014 & $(0.15)$ \\
\hline GDP per cap & & & & & 0.097 & $(0.92)$ & & \\
\hline Current acc. bal. & & & & & $1.493^{* * *}$ & $(6.29)$ & $1.284^{* * *}$ & (5.69) \\
\hline Concentration & & & & & -10.272 & $(-1.29)$ & -21.644 & $(-2.51)$ \\
\hline ADRI & & & & & $3.138^{*}$ & $(2.02)$ & 1.332 & $(0.89)$ \\
\hline Institution & & & & & & & $8.881^{* * * *}$ & $(3.41)$ \\
\hline Adj. $R^{2}(\%)$ & & 11.93 & & 36.46 & & 49.63 & & 54.57 \\
\hline $\mathrm{N}$ & & 311 & & 273 & & 273 & & 273 \\
\hline
\end{tabular}

The dependent variable is BHAR 2011 for the sample banks. BHAR 2011is calculated from June 2011 to December 2011. All the variables are defined in Appendix I. All the accounting variables are pooled at the end of 2010. t-statistics are reported in parentheses . The standard errors for the regressions are estimated with country-level clustering. $* * * * *$, and $*$ represent significance at $1 \%, 5 \%$, and $10 \%$, respectively. 
Table 7. Robustness checks: Risk regressions.

\begin{tabular}{|c|c|c|c|c|c|c|c|c|c|c|c|c|}
\hline & \multirow{2}{*}{\multicolumn{2}{|c|}{$\begin{array}{c}\text { MES } \\
\text { Jan 2010-Dec 2011 } \\
(1) \\
\end{array}$}} & \multirow{2}{*}{\multicolumn{2}{|c|}{$\begin{array}{c}\text { MES } \\
\text { May 2010-Dec 2011 } \\
(2)\end{array}$}} & \multicolumn{2}{|c|}{$\begin{array}{c}\text { Idiosyncratic risk } \\
\text { Jan 2010-Dec 2011 } \\
\end{array}$} & \multicolumn{2}{|c|}{$\begin{array}{c}\text { Idiosyncratic risk } \\
\text { May 2010-Dec } 2011 \\
\end{array}$} & \multicolumn{2}{|c|}{$\begin{array}{c}\text { Beta } \\
\text { Jan 2010-Dec 2011 }\end{array}$} & \multicolumn{2}{|c|}{$\begin{array}{c}\text { Beta } \\
\text { May 2010-Dec 2011 }\end{array}$} \\
\hline & & & & & & & ( & & ( & & $(6$ & \\
\hline & Coef. & $t$-stat & Coef. & $t$-stat & Coef. & $t$-stat & Coef. & $t$-stat & Coef. & $t$-stat & Coef. & $t$-stat \\
\hline Cons & $-6.179^{* * * *}$ & $(-3.73)$ & $-6.504^{* * *}$ & $(-3.87)$ & $0.964^{*}$ & $(1.80)$ & $52.419^{* * * *}$ & $(3.00)$ & $-0.828^{*}$ & $(-1.90)$ & $-0.817^{*}$ & $(-1.88)$ \\
\hline Official & -0.086 & $(-1.55)$ & $-0.100^{*}$ & $(-1.76)$ & -0.395 & $(-0.53)$ & $0.942^{*}$ & $(1.64)$ & $-0.033^{* *}$ & $(-2.31)$ & $-0.034^{* *}$ & $(-2.41)$ \\
\hline Capital & -0.044 & $(-0.57)$ & -0.012 & $(-0.15)$ & $-1.253^{* * *}$ & $(-2.43)$ & -0.418 & $(-0.52)$ & $0.039^{*}$ & $(1.94)$ & $0.040^{*}$ & $(2.02)$ \\
\hline Restriction & $0.111^{* *}$ & $(2.16)$ & $0.125^{* *}$ & $(2.40)$ & 1.247 & $(1.09)$ & $-1.337^{* *}$ & $(-2.42)$ & -0.014 & $(-0.99)$ & -0.013 & $(-0.95)$ \\
\hline Private monitoring & $-0.232^{*}$ & $(-1.92)$ & $-0.265^{*}$ & $(-2.17)$ & $5.930^{*}$ & (2.09) & 1.571 & $(1.28)$ & 0.038 & $(1.24)$ & 0.041 & $(1.34)$ \\
\hline Deposit insurance & $-0.778^{* * *}$ & $(-2.72)$ & $-0.852^{* * *}$ & $(-2.93)$ & 0.023 & $(0.89)$ & $6.507^{* *}$ & $(2.15)$ & $0.382^{* * *}$ & $(5.06)$ & $0.374^{* * * *}$ & $(4.96)$ \\
\hline BHAR & 0.003 & $(1.06)$ & 0.004 & $(1.43)$ & $-0.678^{* * *}$ & $(-2.84)$ & 0.022 & $(0.77)$ & $0.005^{* * *}$ & $(7.64)$ & $0.005^{* * *}$ & $(7.59)$ \\
\hline Tier 1 & -0.012 & $(-0.42)$ & -0.007 & $(-0.25)$ & -0.01 & $(-0.15)$ & $-0.731^{* * *}$ & $(-2.87)$ & $-0.011^{*}$ & $(-1.77)$ & $-0.011^{*}$ & $(-1.80)$ \\
\hline Funding fragility & 0.002 & $(0.24)$ & 0.001 & $(0.11)$ & 0.026 & $(0.32)$ & -0.005 & $(-0.07)$ & $0.003^{*}$ & $(1.82)$ & $0.003^{*}$ & $(1.82)$ \\
\hline Loans & -0.001 & $(-0.08)$ & 0.001 & $(0.12)$ & -4.726 & $(-0.93)$ & 0.029 & $(0.33)$ & 0.001 & $(0.47)$ & 0.001 & $(0.45)$ \\
\hline Income diversity & 0.818 & $(1.57)$ & 0.787 & $(1.49)$ & -2.627 & $(-1.32)$ & -4.997 & $(-0.92)$ & -0.179 & $(-1.33)$ & -0.172 & $(-1.27)$ \\
\hline Size & 0.07 & $(0.36)$ & 0.114 & $(0.57)$ & $-0.179^{*}$ & $(-2.19)$ & -2.753 & $(-1.30)$ & $0.279^{* * *}$ & $(5.27)$ & $0.274^{* * *}$ & $(5.18)$ \\
\hline GDP per cap & -0.007 & $(-0.83)$ & -0.004 & $(-0.45)$ & $-0.560^{* * * *}$ & $(-3.10)$ & $-0.189^{*}$ & $(-2.17)$ & $0.013^{* * *}$ & $(6.09)$ & $0.013^{* * *}$ & $(6.20)$ \\
\hline Current acc. bal. & 0.013 & $(0.70)$ & 0.016 & $(0.89)$ & 6.297 & $(1.03)$ & $-0.601^{* * *}$ & $(-3.12)$ & $-0.035^{* * *}$ & $(-7.31)$ & $-0.034^{* * *}$ & $(-7.07)$ \\
\hline Concentration & 0.519 & $(0.83)$ & 0.477 & $(0.75)$ & $-2.344^{*}$ & $(-2.11)$ & 6.763 & $(1.04)$ & $0.290^{*}$ & $(1.78)$ & $0.291^{*}$ & $(1.79)$ \\
\hline ADRI & 0.184 & $(1.63)$ & 0.177 & $(1.55)$ & $51.975^{* * *}$ & $(3.18)$ & $-2.403^{*}$ & $(-2.03)$ & $-0.153^{* * *}$ & $(-5.18)$ & $-0.154^{* * * *}$ & $(-5.22)$ \\
\hline Adj. $R^{2}(\%)$ & & 8.70 & & 10.72 & & 11.28 & & 11.21 & & 57.50 & & 57.06 \\
\hline $\mathrm{N}$ & & 299 & & 299 & & 313 & & 313 & & 313 & & 313 \\
\hline
\end{tabular}

The dependent variable is MES from May 2010 until the end of 2011 in Panel A and MES from beginning of 2010 until the end of 2011 for the sample banks. All the variables are defined in Appendix I. The accounting variables for the sovereign debt crisis are taken at the end of 2010. t-statistics are reported in parentheses. The standard errors for the regressions are estimated with bank-level clustering. ***, **, * represents significance at $1 \%, 5 \%$, and $10 \%$, respectively. 
Table 8. Robustness checks: Return regressions.

\begin{tabular}{|c|c|c|c|c|c|c|c|c|}
\hline & \multicolumn{4}{|c|}{ sovereign debt crisis - BHAR(Jan 2010-Dec 2011) } & \multicolumn{4}{|c|}{ sovereign debt crisis - BHAR (May 2010-Dec 2011) } \\
\hline & \multicolumn{2}{|c|}{$(1)$} & \multicolumn{2}{|c|}{$(2)$} & \multicolumn{2}{|c|}{$(3)$} & \multicolumn{2}{|c|}{ (4) } \\
\hline & Coef. & $t$-stat & Coef. & $t$-stat & Coef. & $t$-stat & Coef. & $t$-stat \\
\hline Constant & 7.370 & $(0.26)$ & -27.693 & $(-1.10)$ & -30.512 & $(-1.62)$ & -27.693 & $(-1.10)$ \\
\hline Official & $3.098^{* * *}$ & $(2.78)$ & $1.383^{* * *}$ & $(2.64)$ & $1.523^{* *}$ & $(2.21)$ & $1.383^{* * *}$ & $(2.69)$ \\
\hline Capital & 1.383 & $(0.96)$ & 0.875 & $(0.79)$ & -1.384 & $(-1.40)$ & 0.875 & $(0.79)$ \\
\hline Restriction & -0.919 & $(-1.01)$ & -1.05 & $(-1.58)$ & -0.113 & $(-0.16)$ & -1.05 & $(-1.58)$ \\
\hline Private monitoring & -1.475 & $(-0.70)$ & 1.932 & $(1.21)$ & $2.852^{*}$ & $(1.86)$ & 1.932 & $(1.21)$ \\
\hline Deposit insurance & $-12.087^{* * *}$ & $(-2.22)$ & $-14.647^{* * *}$ & $(-3.32)$ & $-3.608^{* * * *}$ & $(-2.83)$ & $-14.647^{* * *}$ & $(-3.32)$ \\
\hline Tier1 & 0.302 & $(0.60)$ & $0.891^{* *}$ & $(1.99)$ & 0.078 & $(0.23)$ & $0.891^{*}$ & $(1.99)$ \\
\hline $\log z$ & -3.468 & $(-0.98)$ & -1.109 & $(-0.37)$ & -3.249 & $(-1.38)$ & -1.109 & $(-0.37)$ \\
\hline Idiosyncratic volatility & $-0.526^{* * *}$ & $(-4.11)$ & $-0.530^{* * *}$ & $(-4.99)$ & $-0.498^{* * * *}$ & $(-5.85)$ & $-0.530^{* * *}$ & $(-4.99)$ \\
\hline Beta & 4.125 & $(0.84)$ & 4.241 & $(1.04)$ & -1.6 & $(-0.49)$ & 4.241 & $(1.04)$ \\
\hline Funding fragility & $-0.362^{* * *}$ & $(-2.71)$ & & & $-0.296^{* * *}$ & $(-3.33)$ & & \\
\hline Deposit & & & $0.423^{* * *}$ & $(4.91)$ & & & $0.423^{* * *}$ & $(4.91)$ \\
\hline Liquid & -0.025 & $(-0.13)$ & & & 0.012 & $(0.09)$ & & \\
\hline Loan & & & 0.141 & $(1.21)$ & & & 0.141 & $(1.21)$ \\
\hline GDP per cap & $-0.277^{*}$ & $(-1.74)$ & & & 0.097 & $(0.92)$ & & \\
\hline Current acc. bal. & $2.567^{* * *}$ & (7.19) & $2.153^{* * *}$ & $(7.29)$ & $1.493^{* * *}$ & $(6.29)$ & $2.153^{* * *}$ & $(7.29)$ \\
\hline Concentration & -2.727 & $(-0.23)$ & -14.775 & $(-1.31)$ & -10.272 & $(-1.29)$ & -14.775 & $(-1.31)$ \\
\hline ADRI & $6.093^{* *}$ & $(2.61)$ & 1.343 & $(0.69)$ & $3.138^{* *}$ & $(2.02)$ & 1.343 & $(0.69)$ \\
\hline Institution & & & $7.127^{* *}$ & $(2.09)$ & & & $7.127^{* *}$ & $(2.09)$ \\
\hline Adj. $\mathrm{R}^{2}(\%)$ & & 33.80 & & 42.83 & & 49.63 & & 42.83 \\
\hline $\mathrm{N}$ & & 273 & & 273 & & 273 & & 273 \\
\hline
\end{tabular}

The dependent variable is BHAR from May 2010 until the end of 2011 in Panel A and BHAR from beginning of 2010 until the end of 2011 for sample banks. All the variables are defined in Appendix I. The accounting variables for the sovereign debt crisis are taken at end of 2010 . $t$-statistics are reported in parentheses. The standard errors for the regressions are estimated with bank-level clustering. ***, **, and * represent significance at $1 \%, 5 \%$, and $10 \%$, respectively. 